\title{
Geologia e litogeoquímica de migmatitos, charnockitos e granulitos do Complexo Guaxupé na região de São João da Boa Vista (SP)
}

\author{
Geology and lithogeochemistry of migmatites, charnockites and \\ granulites of the Guaxupé Complex, São João da Boa Vista region, \\ São Paulo State, Brazil
}

Rodrigo Prudente de Melo ${ }^{1}$, Marcos Aurélio Farias de Oliveira ${ }^{2 *}$

RESUMO: Este trabalho apresenta novos dados geoquímicos e petrológicos da porçấo sul do Complexo Guaxupé. A área de pesquisa é caracterizada pela ocorrência de migmatitos e de granitos charnockíticos que ocorrem como corpo intrusivo na porção nordeste da área. O estudo petrológico e geoquímico de migmatitos bandados mostrou que o paleossoma é geralmente composto por ortogranulitos toleíticos de composição basáltica, que apresentam assinatura de arco de ilha. A fusão parcial desses ortogranulitos básicos gerou neossomas de composição granítica a tonalítica, cálcio-alcalina com alto conteúdo de $\mathrm{SiO}_{2}(>68,9 \%)$, elevada taxa de $(\mathrm{La} / \mathrm{Lu}) \mathrm{N}$ e baixas taxas de $\mathrm{K} / \mathrm{Rb}$. Essas características são coerentes com a fusão parcial de protólitos básicos ricos em $\mathrm{Rb}$ em temperaturas em torno de $820^{\circ} \mathrm{C}$, gerando um líquido félsico na presença de ortopiroxênio e clinopiroxênio. Além disso, o estudo geoquímico de uma suíte de rochas da intrusão granito-charnockítica mostrou que sua evolução é caracterizada pela diferenciação magmática através de fracionamento magmático, que, por sua vez, gerou uma série magmática dada por granito porfirítico seguido por gnaisse charnockítico e finalmente leucognaisse, como produto final de fracionamento magmático. Essas rochas devem ter sido formadas pela fusão parcial de rochas crustais granulíticas de composição diorítica, representadas por gnaisses granulíticos bandados que têm assinatura geoquímica semelhante às rochas magmáticas e ocorrem geograficamente próximos à intrusão magmática.

PALAVRAS-CHAVE: Complexo Guaxupé; granulito; migmatito; gnaisse charnockítico.
ABSTRACT: This paper presents new geochemical and petrological data from the southern portion of the Guaxupé Complex. The research area is characterized by the occurrence of migmatites and an intrusive body of charnockitic granite located on the northeastern portion of the area. Petrological and geochemical studies of the banded migmatites have shown that the paleossome is generally composed by tholeiitic basaltic orthogranulite showing island arc signature. Partial melting of these basic orthogranulites has formed calc-alkalic neossome of granitic to tonalitic composition with high $\mathrm{SiO} 2$ content (> 68.9\%) and high $(\mathrm{La} / \mathrm{Lu}) \mathrm{N}$ ratios, as well as low $K / R b$ ratios. These features are coherent to partial melting of $R b$ rich basic protholits at temperatures around $820^{\circ} \mathrm{C}$ producing a felsic melt in presence of orthopyroxene and clinopyroxene. Moreover, a geochemical study of a rocks suite from the charnockitic intrusion has pointed out that its evolution is characterized by magmatic differentiation through crystal fractionation process, which, in turn, has formed a magmatic series starting with porphyritic granite, followed by charnockitic gneiss and leucogneiss as the final product of crystal fractionation. These rocks, located geographically close to the magmatic intrusion, must have been formed by partial melting of granulitic crustal rocks of dioritic composition, represented by banded granulitic gneisses with a geochemical signature similar to the magmatic rocks.

KEYWORDS: Guaxupé Complex; granulite; migmatite; charnockitic gneiss.

${ }^{1}$ Programa de Pós-Graduação em Geologia Regional, Instituto de Geociências e Ciências Exatas, Universidade Estadual Paulista “Júlio de Mesquita Filho" - UNESP, Rio Claro (SP), Brasil.E-mail: rodrigoprmelo@gmail.com

${ }^{2}$ Departamento de Petrologia e Metalogenia, Instituto de Geociências e Ciências Exatas, Universidade Estadual Paulista "Júlio de Mesquita Filho" - UNESP, Rio Claro (SP), Brasil. E-mail: maurelio@rc.unesp.br

*Autor correspondente

Manuscrito ID 26730. Recebido em: 26/04/2012. Aprovado em: 29/04/2013 


\section{INTRODUÇÃO}

Terrenos metamórficos de alto grau constituem uma grande porção da crosta continental e estão expostos ao longo de faixas móveis e em áreas cratônicas, em sua maioria, de idade pré-cambriana. O estudo da evolução dessas porções de alto grau é complexo, tendo em vista a quantidade de processos que atuaram sobre essas rochas, desde o protólito inicial até sua evolução final. A fusão parcial, que geralmente está associada ao metamorfismo de alto grau, é por si só um processo ímpar na formação de rochas, já que é possível gerar diferentes litótipos a partir de um mesmo protólito, além do fato de que estruturas antigas podem ser destruídas durante consecutivos processos de fusão parcial, dificultando ainda mais as interpretaçóes.

Grande parte do território brasileiro é constituída por terrenos metamórficos de alto grau, ao longo de faixas móveis na região costeira, bem como nas bordas e no interior de crátons. Muitos desses terrenos estão sendo estudados há décadas, mas, devido à complexidade dessas regiōes, ainda persistem muitas dúvidas sobre a evolução dos mesmos.

Neste trabalho, são apresentados novos dados geoquímicos e petrográficos de granulitos, charnockitos e migmatitos que ocorrem na porção SW do Complexo Guaxupé, que constitui um desses terrenos de alto grau. Essas rochas se formaram durante a evolução crustal da unidade no final do Neoproterozoico.

Várias publicações (Janasi 2002, 1997; Campos Neto et al. 1988) abordaram os aspectos geoquímicos de charnockitos do Complexo Guaxupé, os quais foram denominados como suítes mangeríticas.

$\mathrm{Na}$ área estudada, ocorrem principalmente migmatitos bandados ou estromáticos, além de granulitos e granitos que fazem parte de um maciço charnockítico exposto na região NE da área. Nesse contexto, este trabalho aborda os aspectos petrográficos e geoquímicos dos paleossomas e neossomas de migmatitos sob o ponto de vista de suas características geoquímicas, bem como os processos envolvidos na formação e evolução dessas rochas. Busca-se também identificar nos paleossomas a assinatura geoquímica do protólito e investigar as relaçóes genéticas entre a geração de neossomas nos migmatitos e a geração de magmas charnockíticos, no que diz respeito à rocha fonte e processo de formação.

\section{GEOLOGIA REGIONAL}

A área de estudo está localizada a sul da Faixa Brasília, em uma unidade geológica de alto grau metamórfico, fácies granulito, denominada Complexo ou Domínio Guaxupé.
O referido complexo possui formato aproximadamente triangular e é delimitado por rochas sedimentares da Bacia do Paraná, a leste, e por duas grandes estruturas tectônicas: Zona de Cisalhamento Campo do Meio, a N-NE, e Zona de Cisalhamento Ouro Fino, a S-SE (Fig. 1).

Várias denominaçóes englobando essa unidade foram criadas no decorrer da evolução de seu conhecimento. Dentre as denominaçóes mais utilizadas, está a sugerida por Campos Neto et al. (1984), que engloba os complexos Socorro, a sul, e Guaxupé, a norte, em uma mesma unidade, que ocorre em dois lobos separados por rampas laterais de alto ângulo, indicando transporte para E-NE (Fig. 1). Trata-se de uma espessa lasca organizada em uma pilha alóctone dividida em dois domínios: Socorro, a sul; e Guaxupé, a norte (Campos Neto \& Caby 2000).

Segundo Del Lama et al. (2000) e Zanardo et al. (2006), os complexos Guaxupé e Socorro, a sul, formam dois blocos tectônicos continentais alóctones, de crosta inferior, que foram colocados sobre o embasamento arqueano e rochas metassedimentares neoproterozoicas durante a colisão continental que ocorreu no Neoproterozoico. Segundo Zanardo et al. (2006), a norte do Complexo Guaxupé ocorre uma faixa ou cinturão intensamente tectonizado de aproximadamente $20 \mathrm{~km}$ de espessura, com direção E-W, onde podem ser individualizadas sequências metassedimentares psamo-pelíticas, rochas de origem máfica a ultramáfica com lentes de formações ferríferas (interpretadas como uma sequência ofiolítica), ortognaisses e granitos sin-tardi tectônicos. Nessa faixa intensamente tectonizada, estruturalmente denominada de Zona de Cisalhamento Campo do Meio, reconhece-se, por meio de suas características litológicas e geofísicas, um zona de sutura chamada de Zona de Sutura de Alterosa, caracterizada pela presença de lascas ofiolíticas e retro-eclogitos (Godoy et al. 1999).

A Zona de Sutura de Alterosa constitui uma importante discordância geológica na região, marcando o contato entre um terreno granulítico de alto grau, ao sul, e rochas de médio grau associadas ao Grupo Araxá, ao norte. Essa zona de sutura também marca o limite entre duas grandes porçôes cratônicas: Cráton do São Francisco (norte) e o Cráton do Paranapanema (sul).

O Complexo Guaxupé é separado do Complexo Socorro pela Zona de Cisalhamento Ouro Fino, que ocorre entre os dois blocos granulíticos com direção ENEWSW e mergulho vertical. No domínio da Zona de Cisalhamento Ouro Fino, a Sul do Complexo Guaxupé, ocorre uma sequência supracrustal com rochas ortoderivadas associadas, de idade meso-paleoproterozoica, denominada Grupo Itapira. Essas rochas do Grupo Itapira são associadas às rochas infra-crustais ou do embasamento 


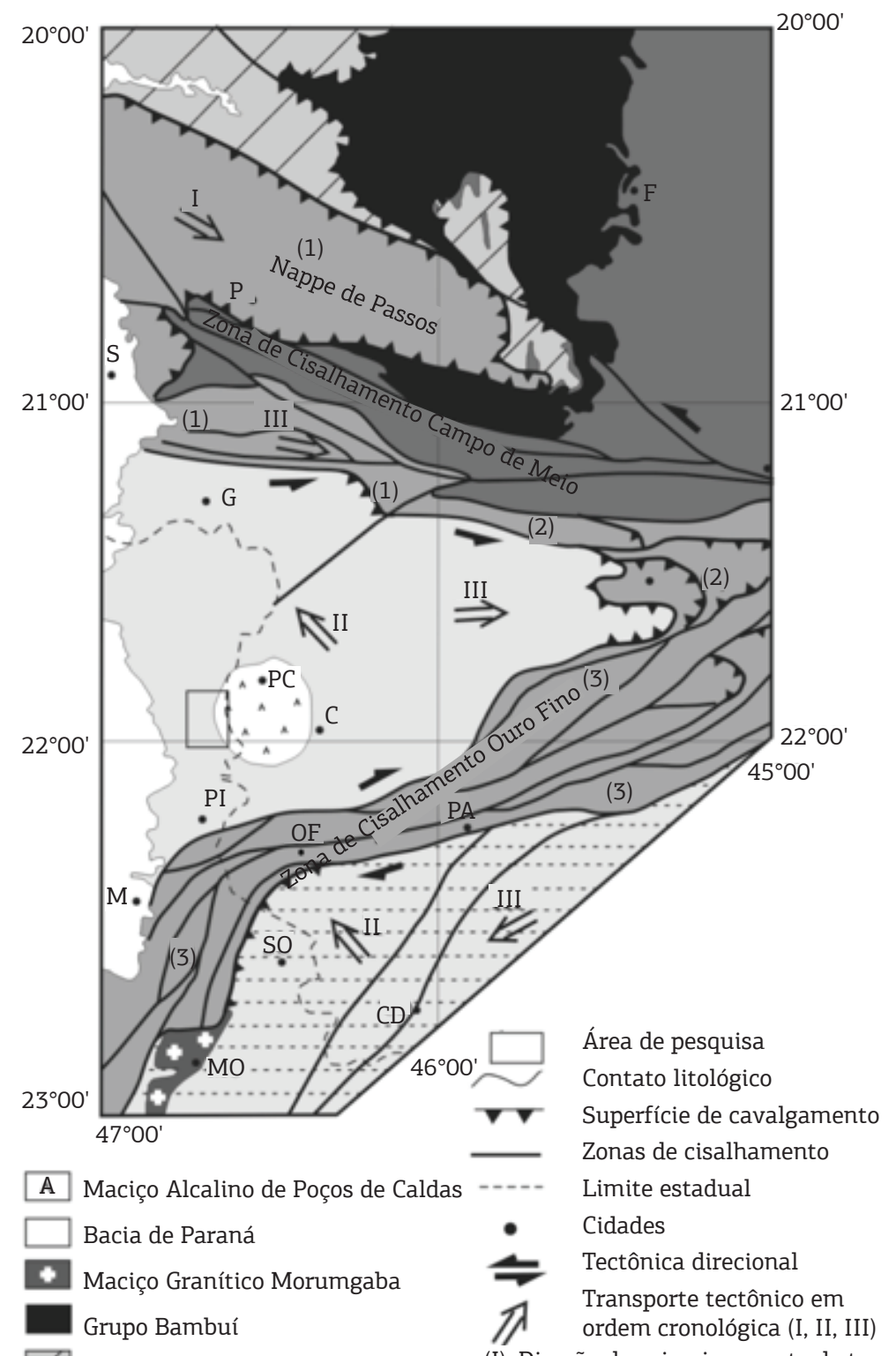

(I): Direção do primeiro evento de transporte tectônico.

(II): Direção do segundo evento de transporte tectônico.

(III): Direção do terceiro evento de transporte

(1) Grupo Araxá, (2) Grupos

Andrelândia e São Del Rei, (3) Grupos Itapira e Amparo

tectônico.

Complexo Guaxupé

[... Complexo Socorro

Complexo Barbacena

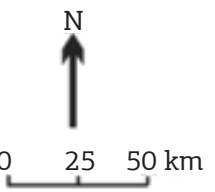

Cidades: C: Caldas; CD: Camanducaia; F: Formiga; G: Guaxupé; M: Mogi Mirim; MO: Morumgaba; P: Passos; PA: Pouso Alegre; PC: Poços de Caldas; PI: Pinhal; S: São Sebastião do Paraiso; SO: Sorocaba; OF: Ouro Fino

Figura 1. Mapa geológico esquemático do Complexo Guaxupé e as unidades geológicas do entorno. Extraído de Fonseca et al. (1979), modificado por Zanardo et al. (2006). 
arqueano Complexo Amparo, o qual pode ser correlato ao Complexo Barbacena (Zanardo et al. 1996).

Segundo Del Lama et al. (2000), entre o Complexo Barbacena e o Complexo Guaxupé ocorrem litologias com evolução tectono-metamórfica similar à porção média e superior do Grupo Araxá.

Segundo Zanardo (2003) e Campos Neto (2000), o Complexo Socorro apresenta litotipos de composição e evolução similar aos encontrados no Complexo Guaxupé, e a diferença entre ambos reside apenas na ocorrência de maior quantidade de granitoides e menor quantidade de rochas metassedimentares, granulitos e charnockitos no Complexo Socorro.

O Complexo Guaxupé é constituído por rochas de natureza intermediária a ácida, ortoderivadas, com intercalaçôes de rochas metassedimentares (pelíticos, psamíticos e carbonáticos), rochas máficas e mais raramente rochas ultramáficas (Zanardo et al. 2006). São granulitos félsicos a máficos, gnaisses graníticos, paragnaisses, quartzitos, xistos, mármores e lentes de rochas calciossilicáticas (Del Lama et al. 2000). A porçấo estudada corresponde à extremidade sul deste complexo e refere-se à unidade migmatítica superior de Campos Neto e Caby (2000).

\section{LITOESTRATIGRAFIA}

A área de pesquisa está localizada na região do município de São João da Boa Vista, SP (Fig. 2), porção sul do Complexo Guaxupé. Nessa área, ocorrem predominantemente migmatitos e gnaisses com estrutura e composição variada. A distribuição espacial e classificação das unidades litoestratigráficas abordadas nesta pesquisa têm como base os trabalhos de Oliveira et al. (1984) e Morales (1988), que mapearam a área de estudo em escala 1:50.000 (Fig. 2).

As unidades são assim denominadas: gnaisses granulíticos bandados (Gnb); biotita-diopsídio anfibolitos (A); gnaisses kinzigíticos (Gnk); migmatitos predominantemente estromáticos $(\mathrm{Mb})$; migmatitos predominantemente estromáticos com predomínio de porçôes leucocráticas graníticas $(\mathrm{Mb}(\mathrm{g}))$; migmatito com predomínio de estrutura oftálmica (Mo); migmatitos com predomínio de estrutura nebulítica $(\mathrm{Mn})$; gnaisses charnockíticos (Gch); leucognaisses (Lg); granitos porfiríticos (GP); e gnaisses ocelares (Go). Considerando-se que a classificaçáo "migmatitos com predomínio da estrutura oftálmica" náo consta da proposta de Wimmenauer e Brihni (2007), propóe-se a denominação de gnaisses ocelares.

\section{Biotita-diopsídio anfibolito (hornblenda xisto)}

$\mathrm{Na}$ porção nordeste da área, afloram dois pequenos corpos de dimensões hectométricas de uma rocha ultramelanocrática de granulação grossa e estrutura maciça, composta essencialmente por grandes cristais ( $\leq 400$ micras) de hornblenda (> 80\%). Sendo de composição ultrabásica, essa unidade foi classificada por Morales (1988) como biotita-diopsídio anfibolito. Além de anfibólio, ocorrem também biotita $(\leq 3 \%)$, diopsídio $(\leq 3 \%)$, plagioclásio $(\leq 7 \%)$ e eventualmente quartzo.

\section{Paragnaisses}

Paragnaisses geralmente ocorrem como paleossomas de migmatitos e basicamente são de dois tipos. O primeiro tipo é composto por cordierita $( \pm 25 \%)$, feldspato potássico $( \pm 20 \%)$, silimanita $( \pm 15 \%)$, oligoclásio $(<15 \%)$, granada $( \pm 7 \%)$ e biotita $( \pm 4 \%)$, podendo conter ou não espinélio. Este é classificado como granada-silimanita-cordierita gnaisse ou gnaisse kinzigítico. A ocorrência mais expressiva dessa rocha está localizada na porção SW da área, onde aflora um corpo de cerca de $2 \mathrm{~km}$ de comprimento por $400 \mathrm{~m}$ de largura (Fig. 2). O segundo tipo é menos comum e corresponde a gnaisses calciossilicáticos que, via de regra, só foram observados como paleossomas de migmatitos. Apresenta composição mineralógica variada, com minerais ricos em Ca sempre acompanhados por plagioclásio de elevado conteúdo de An. Essas rochas são interpretadas como sedimentos que foram colocados em grandes profundidades durante a evolução da unidade e metamorfisados sob condiçóes de alto grau.

\section{Migmatitos}

A fusão parcial é o principal processo formador de rocha na área de estudo e, dessa forma, nela são encontrados vários tipos estruturais de migmatitos. No entanto, os mais frequentes são aqueles com estrutura estromática (Figs. 3A e D), ocelar e nebulítica. Não é incomum encontrar em escala de afloramento as estruturas "schlieren" (Fig. 3C), dobrada (Fig. 3E) e de dilatação de Mehnert (1968), que geralmente ocorrem associadas a migmatito bandado.

Migmatito estromatito, ou informalmente denominado migmatito bandado, é o tipo que ocorre com maior frequência, sendo caracterizado por bandamento composicional com intercalaçóes de bandas leucocráticas de cor cinza claro a róseo, bandas mesocráticas de cor cinza e bandas melanocráticas de cor preta, compondo respectivamente o leucossoma, mesossoma e melanossoma.

Muitas vezes, o mesossoma compóe o paleossoma da rocha e, desta maneira, carrega as características do 


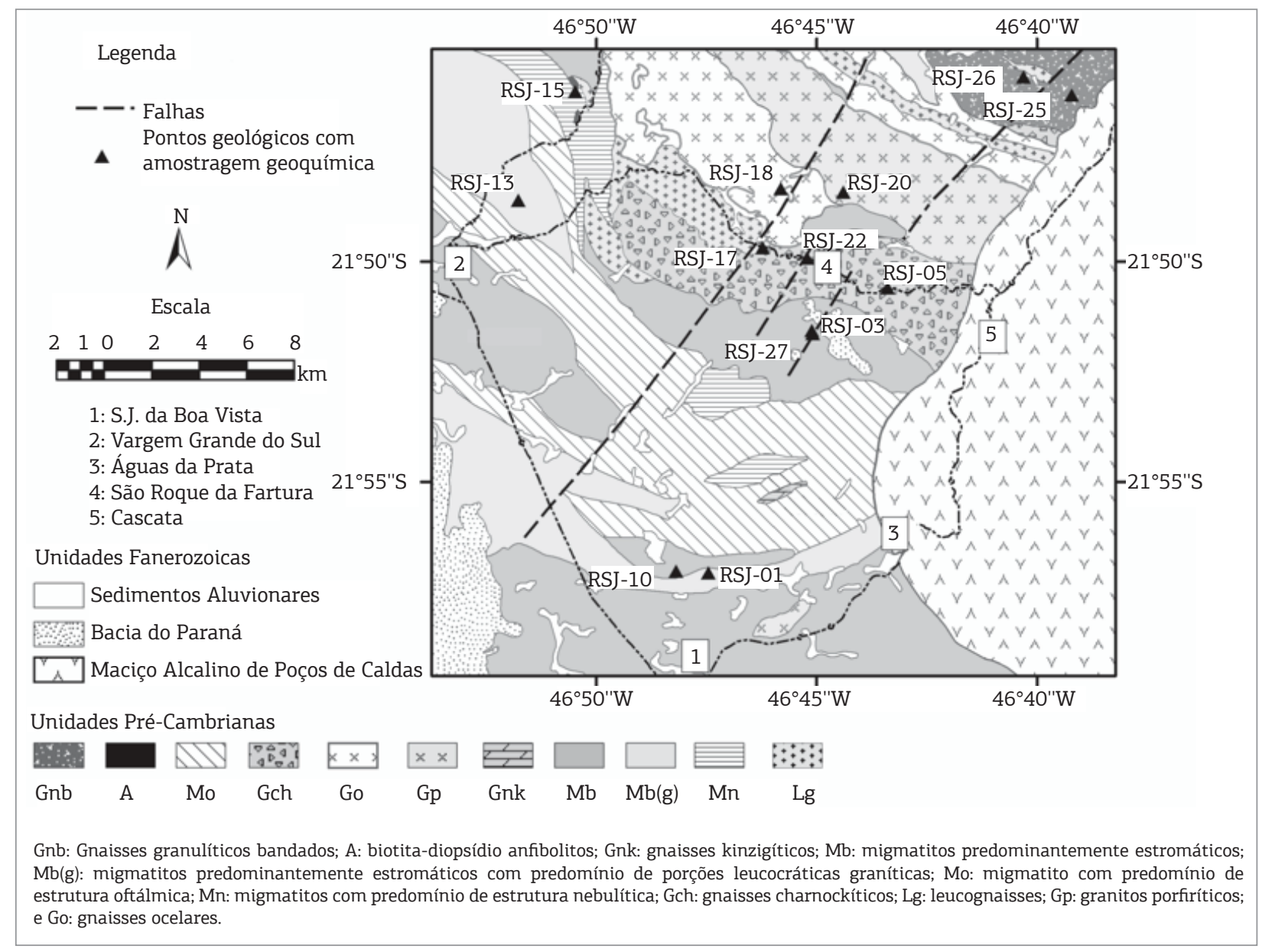

Figura 2. Mapa geológico e de pontos com amostragem geoquímica. Arcabouço geológico extraído de Morales (1988).

protólito, podendo ser dividido, segundo sua gênese, em paraderivado (representado por gnaisse quartzo feldspático, gnaisses kinzigíticos e rochas calciossilicáticas) e ortoderivado, correspondendo a gnaisses granulíticos de composiçấo básica.

O paleossoma granulítico de composição básica (Figs. $4 \mathrm{~F}$ e $4 \mathrm{H}$ ) é composto por plagioclásio (entre 40 e $25 \%$ ), diopsídio (entre 10 e $30 \%$ ), ortopiroxênio (entre 3 e $15 \%$ ), hornblenda (em torno de 30\%) e biotita (em torno de 12\%). Em alguns casos, observam-se dois tipos de hornblenda, uma de cor castanha e outra de cor verde oliva, formada a partir do diopsídio e aparentemente em desequilíbrio com a paragênese de mais alto grau.

O paleossoma composto por rochas calciossilicáticas sempre apresenta grande variedade mineralógica e textural, podendo ser composto por plagioclásio (cerca de 45\%), granada (cerca de 20\%), hedenbergita (em torno de $10 \%$ ) e escapolita (mais de $1 \%$ ) ou conter apenas diopsídio e plagioclásio. Uma das amostras estudadas apresenta associação de hedenbergita e granada, estando o cristal de hedenbergita envolto pela granada em uma reaçáo onde ocorre consumo do piroxênio para a formação da granada (Fig. 4A). Associada ao cristal de granada, observa-se textura simplectítica, com a inclusão de quartzo e minerais opacos. Além disso, o contato dos cristais de plagioclásio é poligonal com pontos tríplices, indicando estabilidade na sua recristalização.

Os leucossomas/neossomas são gnaisses ácidos de tendência cálcio-alcalina, sendo representados por tonalitos, monzogranítos e sienogranítos (Fig. 4G). Segundo Morales (1988) e Morales e Hasui (1990), os leucossomas ou mobilizados quartzo-feldspáticos podem ser interpretados em termos de três fases de migmatização, sendo a primeira fase anatética, a segunda associada à deformaçáo principal e a terceira tardi a pós-tectônica, representada por pequenos corpos lenticulares, veios e diques irregulares.

Aparentemente, a primeira fase de anatexia é caracterizada por rochas com menor conteúdo de $\mathrm{SiO}_{2}$, nas quais o neossoma apresenta cor cinza clara e composição tonalítica 

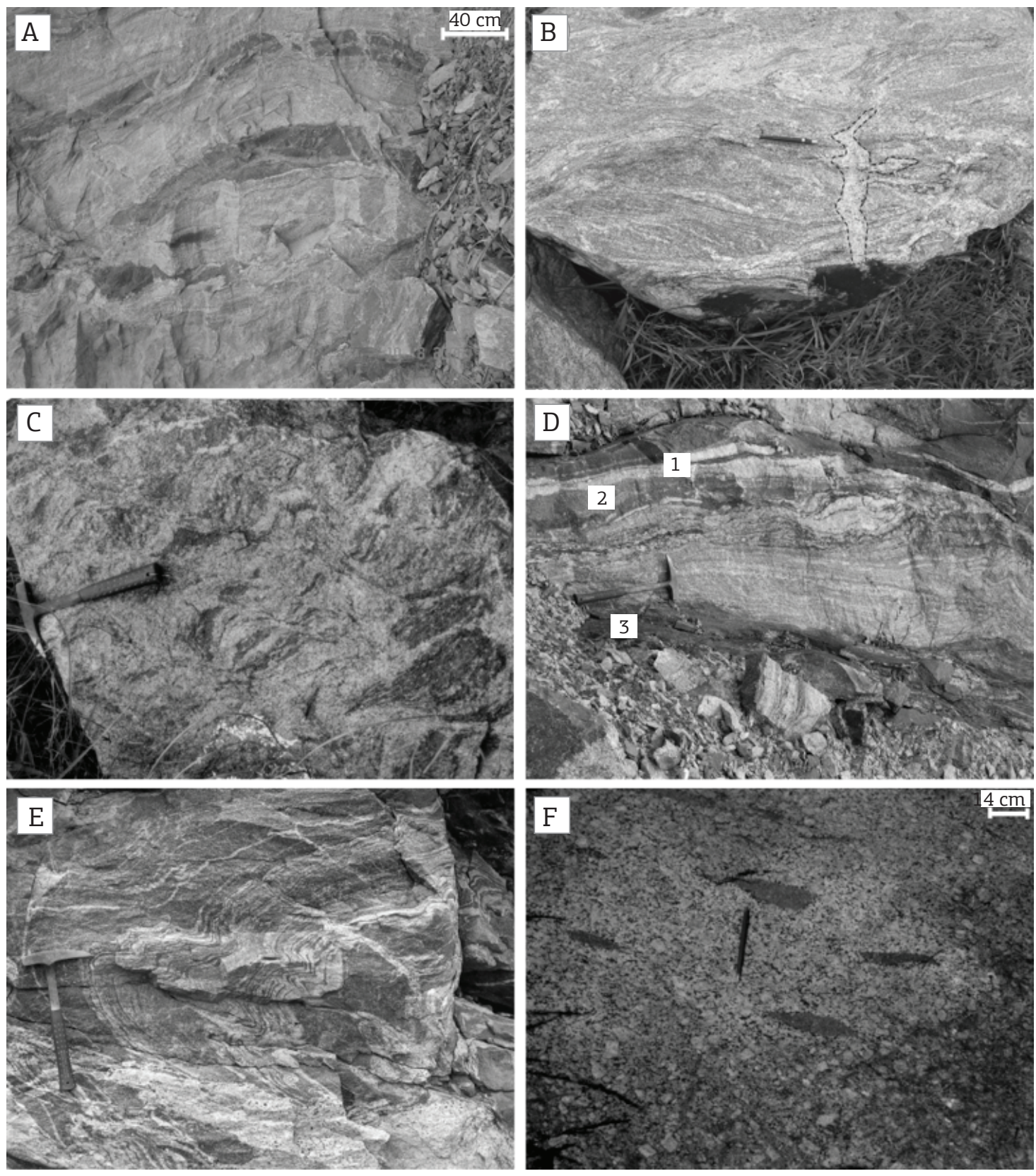

Figura 3. Litotipos e estruturas de rochas da área de estudo. (A) migmatito estromático brechado; (B) dique pegmatítico de composição granítica (linha tracejada) discordante da foliação principal; (C) migmatito com estrutura "schlieren"; (D) migmatito estromático onde se observam: 1 - leucossoma; 2 - mesossoma; 3 - melanossoma; (E) migmatito estromátito dobrado; (F) granito porfirítico com xenólitos de anfibolito.

a granodiorítica. No entanto, essa afirmação é baseada em apenas uma amostra (RSJ-10D) devido à dificuldade de se coletarem grandes volumes desse material, uma vez que os neossomas apresentam pequena espessura. A segunda fase é granítica e composta por plagioclásio (entre 15 e 45\%), feldspato potássico (normalmente entre 20 e 50\%), quartzo (entre 10 e $35 \%$ ) e biotita, que está presente nos leucossomas/neossomas analisados $(4-10 \%)$. Os minerais acessórios presentes geralmente são opacos, apatita e zircão, podendo, em alguns casos, ocorrer allanita.

Segundo Wimmenauer e Bryhni (2007), melanossomas são formados por minerais máficos e representam a porção mais escura dos migmatitos. No caso das rochas da área de estudo, o melanossoma é formado por hornblenda e biotita ocorrendo juntos ou sozinhos, podendo também estar associados a clinopiroxênio. (Fig. 3D). 

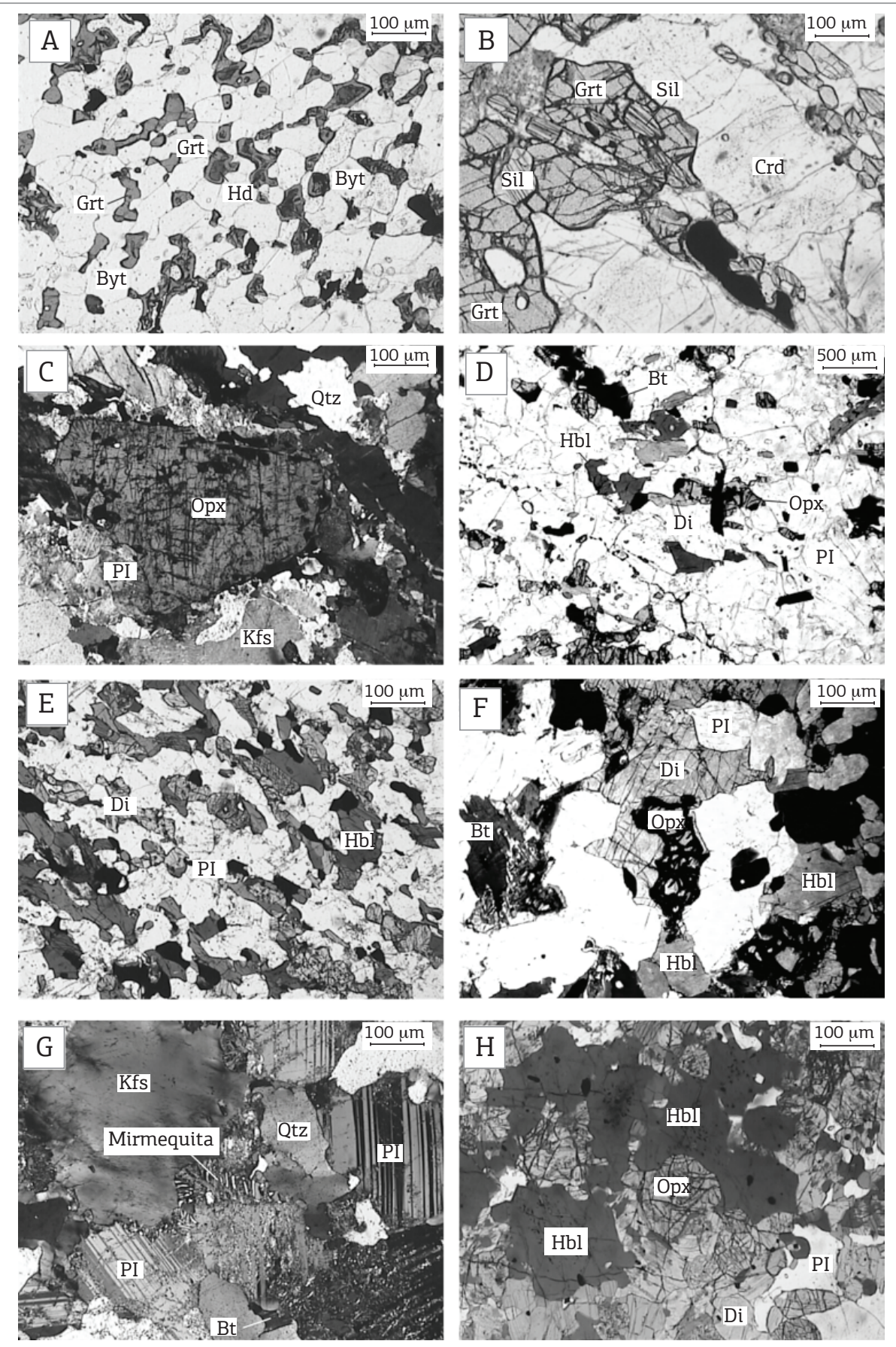

Abreviações dos minerais segundo Kretz (1983) - Qtz: quartzo; Grt: granada; Hd: hedenbergita; Byt: bytownita; Sil: silimanita; Crd: cordierita; Opx: ortopiroxênio; Pl: plagioclásio; Kfs: feldspato potássico; Bt: biotita; Hbl: hornblenda; Di: diopsídio.

Figura 4. Fotomicrografias de alguns dos principais litotipos que ocorrem na área. (A) paragnaisse cálciosilicatado presente como paleossomas de migmatitos estromáticos, apresentando textura dada pela presença de hedenbergita no centro rodeada por uma corona de granada cálcica; (B) paragnaisse kinzigítico presente como paleossoma de migmatitos estromáticos, apresentando cristais de granada, silimanita e cordierita; (C) gnaisse charnockítico apresentando cristal de ortopiroxênio (hiperstênio) no centro da foto; (D) gnaisse granulítico bandado apresentando como mineralogia clinopiroxênio, ortopitroxênio hornblenda, biotita e plagioclásio; (E) gnaisse diopsídio anfibolítico que ocorre como melanossoma em migmatitos estromáticos, apresentando como mineralogia plagioclásio, diopsídio e hornblenda; (F) gnaisse ortogranulítico básico que ocorre como paleossoma em migmatito estromático, apresentando diopsídio, ortopiroxênio, biotita, hornblenda e plagioclásio; (G) neossoma de composição granítica, apresentando textura mirmequítica; $(\mathrm{H})$ gnaisse ortogranulítico básico (amostra RSJ-48), apresentando composição mineralógica dada pela predominância de ortopiroxênio e hornblenda e ausência de biotita. Nicóis cruzados somente nas fotos C e G. 
O migmatito nebulítico agrupa rochas leucocráticas a hololeucocráticas, com composição granítica a granodiorítica, preservando estruturas "schlieren" e bandas muito difusas.

\section{Gnaisses granulíticos bandados}

Unidade formada pelo predomínio de granulitos de composição diorítica a quartzo diorítica, algumas vezes estruturada em bandas mesocráticas, gnaissificadas, de granulação média. Quando bandada, as camadas mesocráticas estão intercaladas com camadas leucocráticas de menor espessura e frequência, compostas basicamente por gnaisses granodioríticos a tonalíticos. É composta por oligoclásio/ andesina $( \pm 50 \%)$, diopsídio (> 3\%) ortopiroxênio $(<5 \%)$, hornblenda $( \pm 10 \%)$, quartzo $( \pm 10 \%)$ e biotita $( \pm 4 \%)$ (Fig. 4D).

No sudoeste dessa unidade, ocorrem corpos descontínuos e aparentemente lenticulares de granada granulito, não mapeáveis na escala 1:50.000. Trata-se de uma rocha foliada com textura granoblástica formada por andesina ( $\pm 40 \%)$, quartzo $( \pm 27 \%)$, feldspato potássico $( \pm 10 \%)$, biotita $( \pm 10 \%)$, granada $( \pm 07 \%)$ e ferro-hiperstênio $( \pm 6 \%)$. Próximo a esses corpos, ocorre gnaisse de granulação média a grossa, composto por granada, biotita, plagioclásio, quartzo e feldspato potássico, classificado como biotita - granada gnaisse.

\section{Granito porfirítico e gnaisse ocelar}

$\mathrm{Na}$ porção norte da área, são comuns granitos com megacristais de feldspato potássico (Fig. 3F), euedrais, de 1 a $6 \mathrm{~cm}$ de comprimento. Em locais onde a deformação foi mais intensa, a gnaissificação é marcada por textura “augen”. A composição mineralógica é caracterizada por fenocristais de feldspato alcalino mesopertítico de cor rosa a branca $( \pm 39 \%)$, plagioclásio (oligoclásio, $\pm 23 \%$ ), quartzo $( \pm 18 \%)$, biotita $( \pm 11 \%)$ e hornblenda $( \pm 8 \%)$, podendo ser classificada como hornblenda granito. São rochas de composição granítica, cálcio-alcalinas, no limite entre o campo das rochas ácidas e intermediárias.

Alguns megacristais de feldspato potássico apresentam coronas de albita formadas pela migração localizada de sódio derivado da imiscibilidade da pertita. Em campo, observa-se a passagem lateral e gradual desses granitos para gnaisses charnockíticos de cor esverdeada.

\section{Gnaisse charnockítico}

Segundo Frost e Frost (2008), charnockito é um termo geral que pode ser aplicado a rochas ígneas ou ortognaisses graníticos com ortopiroxênio. A unidade denominada gnaisse charnockítico delimita um corpo com direção aproximadamente E-W na porção centro-norte da área. Nela, há predomínio de rochas portadoras de restos de hiperstênio, composição álcali-granítica a granítica e, mais raramente, quartzo-sienítica (mangerito), de cor verde escuro a cinza claro, com granulação média a grossa e portadoras de foliação gnáissica, em algumas porções do corpo. É composta por feldspato alcalino mesopertítico, oligoclásio, quartzo, biotita, anfibólio (ferro edenita hornblenda), hiperstênio (Fig. 4C) e, mais raramente, hedenbergita. Corpos alongados de dimensóes métricas a decamétricas de leucognaisses estấo associados à borda dessa unidade.

\section{Leucognaisse}

A ocorrência de leucognaisse (alaskito ou leucogranito gnaissificado) geralmente marca a borda de corpos de granitos porfiríticos ou gnaisses charnockíticos. Trata-se de gnaisses róseos, com estrutura "flaser", graníticos a álcaligraníticos, granulação fina a média, compostos por feldspato potássico, oligoclásio e quartzo, com pouca ou nenhuma biotita ou mineral máfico. Próximo ao contato com os corpos charnockíticos, observam-se ocorrências métricas a decamétricas de biotita anfibolito que também são comuns em afloramentos de gnaisse charnockítico (RSJ-25D), bem como de granito porfirítico. Aparentemente, são xenólitos máficos de granulação fina a média.

\section{GEOLOGIA ESTRUTURAL}

Segundo Del Lama et al. (2000), o Complexo Guaxupé preserva foliação principal W - WNW, paralela ao bandamento composicional. Essa foliação é relativamente constante e forma arranjo anastomosado ou dobras abertas a isoclinais.

Segundo Morales e Hasui (1990), é possível identificar três fases de deformação, todas associadas a eventos de anatexia. $\mathrm{O}$ primeiro evento é anterior à foliação principal e é representado por neossomas que ocorrem no paleossoma de migmatitos formados na segunda fase. A segunda fase de deformação contém a foliação principal que é paralela ao bandamento composicional de migmatitos, caracterizada pela intercalação de bandas leucocráticas de cor rósea e bandas mesocráticas a melanocráticas. Concordantes com a foliação principal, estão os planos axiais de dobras abertas a isoclinais. A terceira fase é marcada pela intrusão de rochas graníticas, pegmatíticas ou aplíticas, e róseas, na forma de diques ou bolsóes discordantes da foliação principal (Fig. 3B).

Conforme descrito por Morales e Hasui (1990), em alguns afloramentos de migmatito bandado é possível observar dois tipos de neossoma: um é predominantemente 
branco acinzentado, com bandas de composição tonalítica, geralmente de pequena espessura, muitas vezes irregulares e com contato difuso, e quase sempre estão dobradas em dobras fechadas a isoclinais (Fig. 3E). O outro tipo corresponde a neossoma róseo de composiçáo granítica, com contato bem marcado (Fig. 3D), cujas bandas sáo relativamente mais espessas, paralelas à foliação principal.

A foliação principal é formada pela orientaçẫo: de cristais de minerais planares; do maior alongamento de cristais inequidimensionais; de megacristais euedrais; de aglomerados de quartzo; de agregados lenticulares de minerais máficos; e de planos de recristalização com granulação mais fina que o normal. Essa foliação apresenta atitude nos máximos de concentração de polos em torno de N70W/35SW; no entanto, a distribuição de polos de planos ao longo de um alinhamento em uma guirlanda sugere dobras com eixos que mergulham para $\mathrm{S} 35 \mathrm{~W} / 35^{\circ}$.

A evolução dos eventos de deformação deve configurar um processo contínuo relacionado à exumaçáo crustal. A principal fase de deformaçáo ocorreu durante a deformação dúctil; já a última fase deve ter ocorrido em ambiente dúctil-rúptil, no qual a intrusão de corpos graníticos, pegmatíticos e aplíticos, gerados por fusão parcial nos estágios finais da exumação, aproveitou planos de descontinuidade para se alojar. A deformação rúptil marca os estágios finais da evolução tectônica, na qual, segundo Morales e Hasui (1990), a gênese das estruturas rúpteis resulta da fragmentação que ocorreu após a deformação plástica com as rochas já em estado dúctil-rúptil.

No Mesozoico, com o desenvolvimento do Maciço Alcalino de Poços de Caldas, essas estruturas foram reativadas e alojaram diques de tinguaíto. Essa deformação é acompanhada por um metamorfismo de baixo grau, provocando saussuritização, epidotização, cloritização e sericitização, mais intensas nas zonas fraturadas. As estruturas rúpteis estão bem marcadas em alinhamentos de drenagem com direção NE-SW e constituem planos de falhas com atitude N30E-N40E/subverticais.

\section{GEOQUÍMICA}

Para a apresentação do estudo geoquímico, os dados foram separados em grupos denominados "Suítes" no texto a seguir. Esses agrupamentos baseiam-se principalmente no contexto geológico das amostras, bem como nas suas afinidades geoquímicas e petrográficas.

Assim, denomina-se: Suíte 01, grupo composto por amostras de paleossomas ortogranulíticos de composição básica, coletadas principalmente em migmatitos com estrutura estromática e dobrada, que ocorrem na porção central e sul da área de pesquisa; Suíte 02, grupo formado por amostras de gnaisse granulítico bandado (Gnb da Fig. 2), granito porfirítico gnaissificado ou não (Go e Gp da Fig. 2), gnaisse charnockítico (Gch da Fig. 2) e leucognaisse (Lg da Fig. 2), que ocorrem restritos à porção nordeste da área de pesquisa (Fig. 2); Suíte 03, grupo formado por amostras de neossomas leucocráticos de composição granítica, coletadas em migmatitos predominantemente estromáticos da porção central e sul da área; Suíte 04, grupo formado por amostras de biotita - anfibolitos com ou sem diopsídio, que ocorrem como "boudins", associados a migmatitos ou a gnaisses charnockíticos, e a amostra de biotita diopsídio anfibolito ou hornblenda xisto (Fig. 2A) que aflora na porção NW da área como corpos de rocha de composição ultrabásica ultramelanocrática.

A Tab. 1 apresenta as composiçóes químicas de 20 amostras representativas da área de pesquisa. Os procedimentos de análise dos óxidos dos elementos maiores, menores e traços foram executados segundo Moreno et al. (1997). As análises de elementos maiores e alguns menores e traços foram executadas no Laboratório de Geoquímica do Departamento de Petrologia e Metalogenia do Instituto de Geociências e Ciências Exatas (IGCE) da Universidade Estadual Paulista "Júlio de Mesquita Filho" (UNESP) - LABOGEO. Das 20 amostras analisadas por fluorescência de raios X, 10 foram escolhidas para serem analisadas por ICP-MS no Activation Laboratories Ltda., para a determinação de elementos menores, traços e terras raras (ETR), sendo 3 selecionadas para análise de ETR no LABOGEO (Tab. 1).

\section{Elementos maiores}

A Suíte 01 é formada por rochas básicas com teor de $\mathrm{SiO}_{2}$ entre 45,3 e 49,5\% (Tab. 1), afinidade toleítica (Fig. 5A) e classificadas como basaltos (Fig. 5B).

A Suíte 02 apresenta ampla variação dos teores de $\mathrm{SiO}_{2}$ (56,14 a 72,59\%), $\mathrm{MgO}(0,11$ a 3,20\%), FeOt (2,43 a $7,89 \%)$ e $\mathrm{K}_{2} \mathrm{O}(1,95$ e $6,26 \%)$. São rochas com tendência cálcio-alcalina (Fig. 5A), e seu conteúdo de $\mathrm{SiO}_{2}$ varia de intermediário a ácido. No diagrama de classificação magmática, esse grupo forma uma série contínua do campo do traqui-andesito ao campo do riólito (Fig. 5B).

A Suíte 03 apresenta pequena variação nos teores de $\mathrm{SiO}_{2}$ (68,92 e 75,58\%); são rochas cálcio-alcalinas (Fig. 5A) e de composição ácida (dacitos a riolitos - Fig. 5B).

A Suíte 04 apresenta moderada variação nos teores de $\mathrm{SiO}_{2}$, com composição desde ultrabásica $\left(\mathrm{SiO}_{2}\right.$ menor que $45 \%)$ até intermediária $(54,91 \%)$. Apresenta elevado conteúdo de $\mathrm{MgO}$ e $\mathrm{CaO}$ e varia desde picro-basalto até basalto traqui-andesítico (Fig. 5B).

Os diagramas de variação binária usando $\mathrm{SiO}_{2}$ como índice de discriminação (Fig. 6) mostram as diferenças 


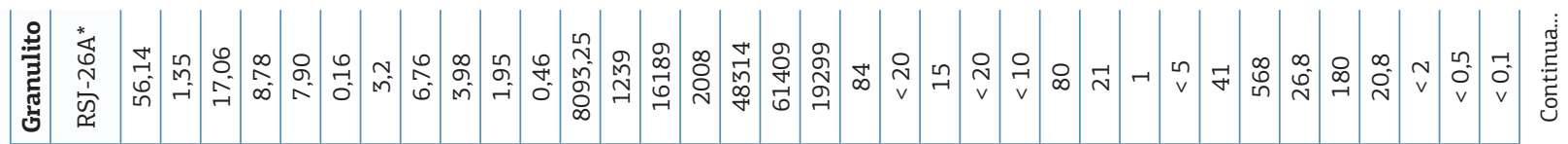

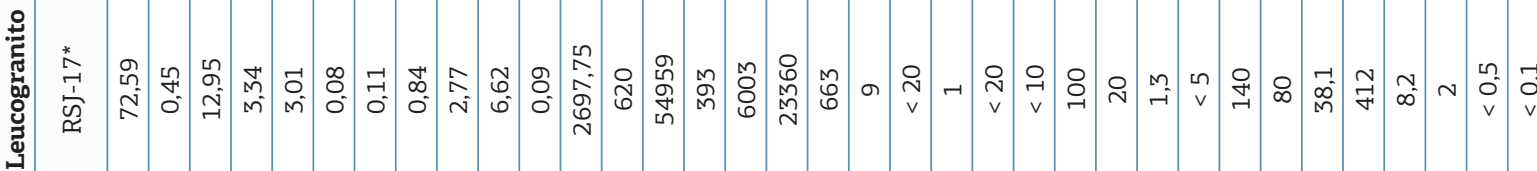

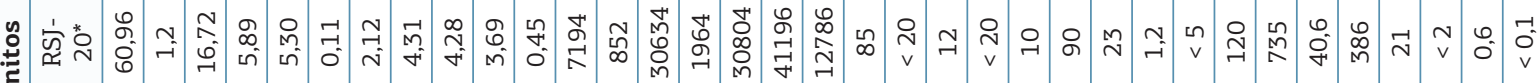

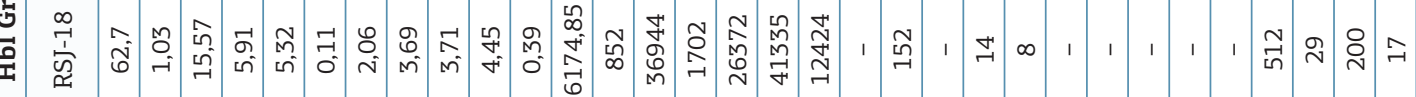

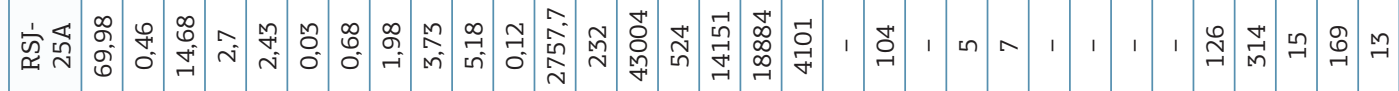
(2)

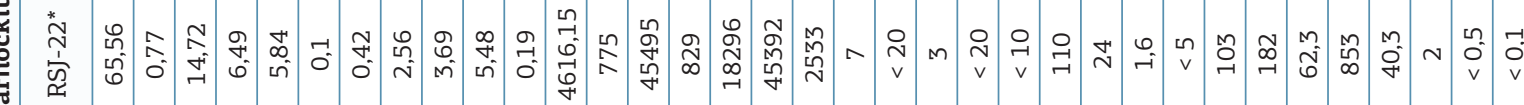

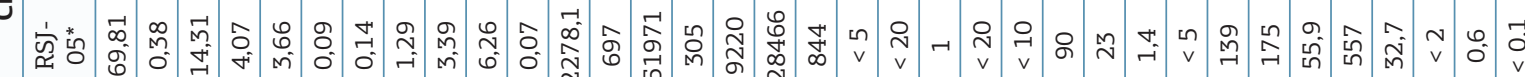

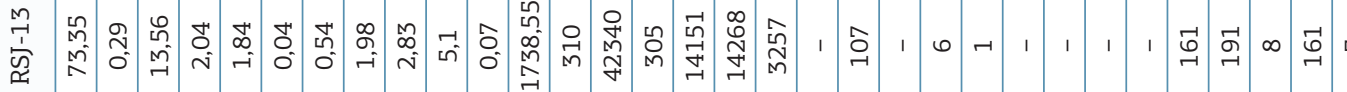

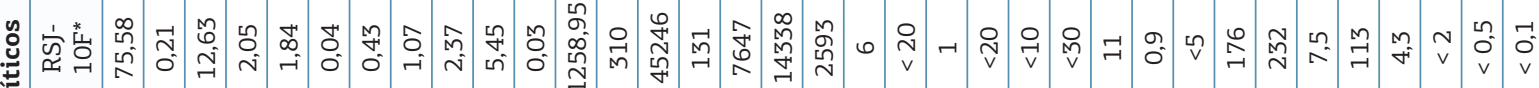

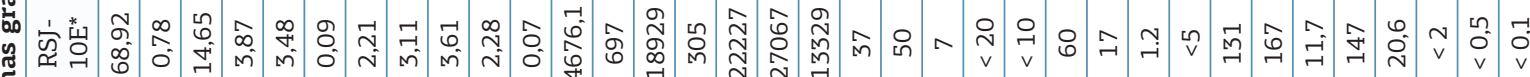

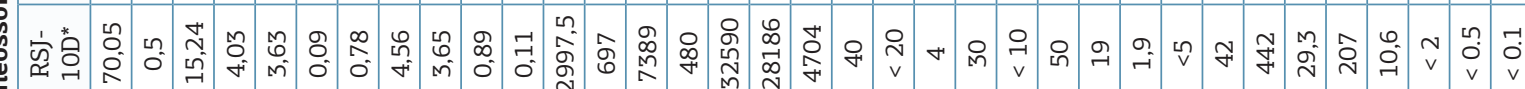

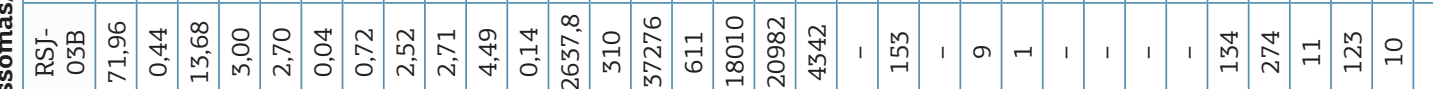

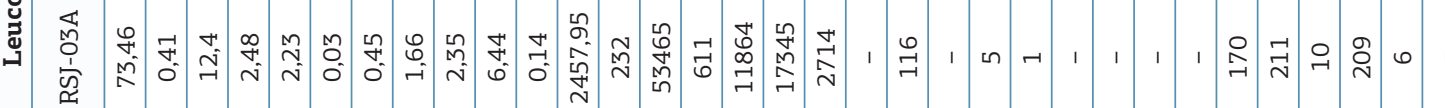

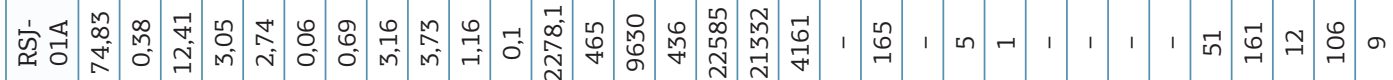

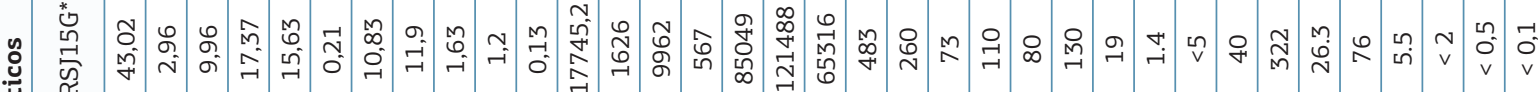




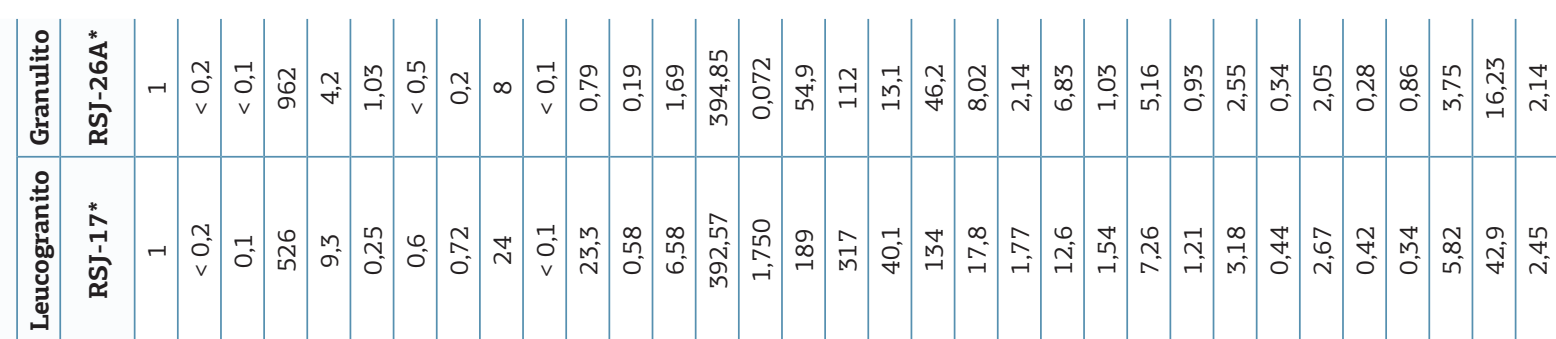

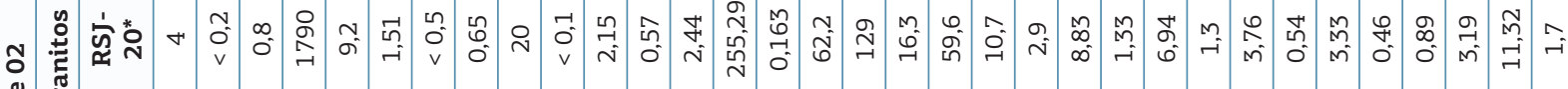

芯

突

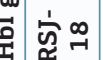

空

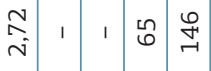

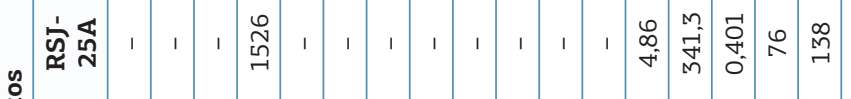

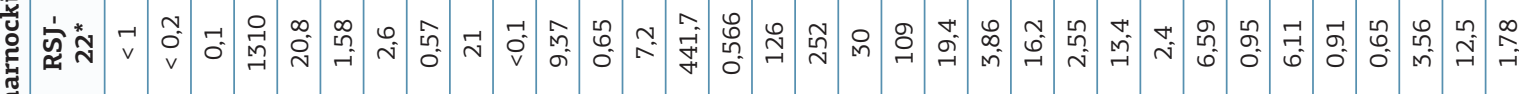
ป็

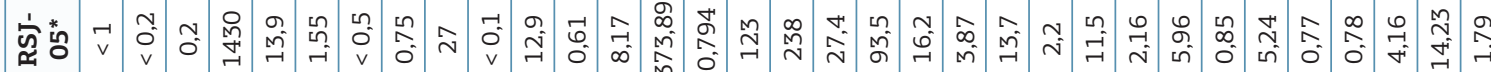

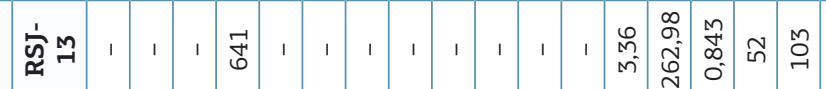

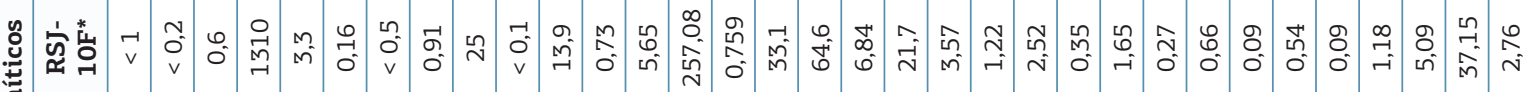

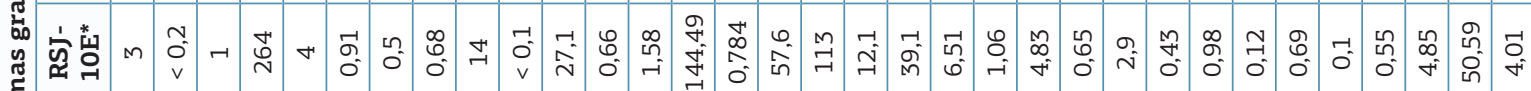
\%

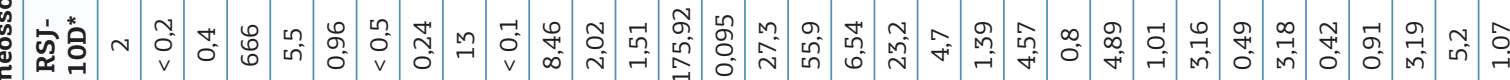

\begin{tabular}{|c|c|c|c|c|c|c|c|c|c|c|c|c|c|c|c|c|c|c|c|c|c|c|c|c|c|c|c|}
\hline 空罢 & & ' & & 昜 & & & 1 & & & & 1 & 1 胥 & 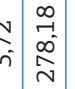 & $\mid \begin{array}{l}0 \\
0 \\
0 \\
0 \\
0 \\
0\end{array}$ & & & 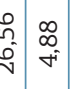 & $\underset{i}{m}$ & $\hat{m^{\prime}} \quad 1$ & $\begin{array}{ll}1 & m \\
\stackrel{N}{N}\end{array}$ & 1 孚 & $\begin{array}{ll}\vec{t} & 1 \\
& \end{array}$ & $\begin{array}{l}n \\
\stackrel{n}{-} \\
-i\end{array}$ & $\begin{array}{l}n \\
\tilde{0} \\
0\end{array}$ & & & \\
\hline$\frac{1}{5}$ & & I & & $\begin{array}{l}0 \\
\bar{m} \\
0\end{array}$ & 1 & 1 & 1 & 1 & & 1 & 1 & $1)$ & 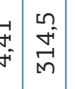 & $\left.\mid \begin{array}{l}0 \\
0 \\
\infty \\
0\end{array}\right]$ & 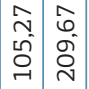 & $\begin{array}{l}\text { M } \\
- \\
\infty\end{array}$ & 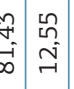 & 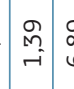 & \begin{tabular}{|l|l} 
& \\
0 & \\
0 & \\
0 &
\end{tabular} & $1\left|\begin{array}{c}\mathcal{N} \\
\mathcal{N}\end{array}\right|$ & $1 \stackrel{m}{\rightarrow}$ & fi & $\begin{array}{l}\vec{g} \\
\vec{i}\end{array}$ & & & 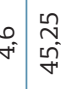 & \\
\hline
\end{tabular}

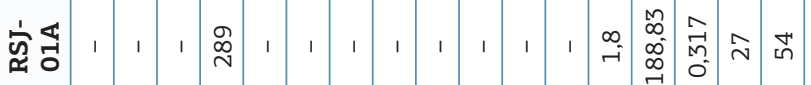

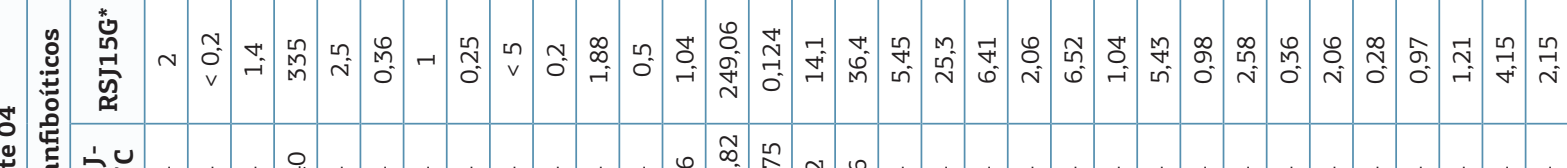

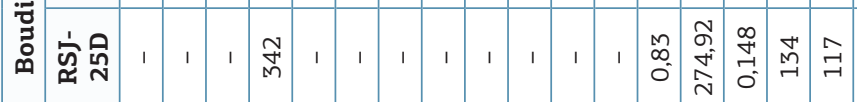

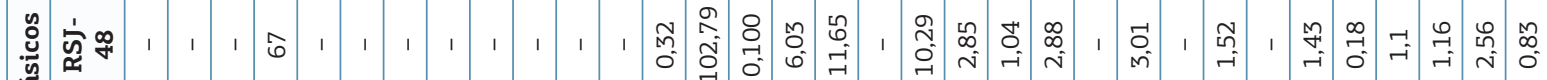

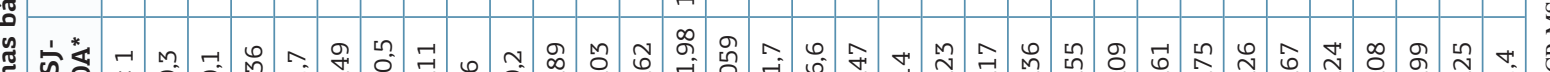

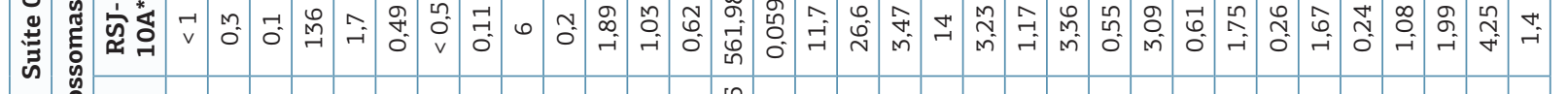

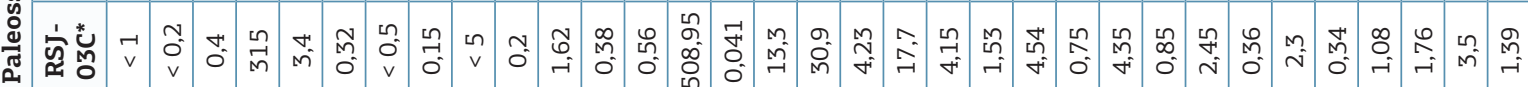




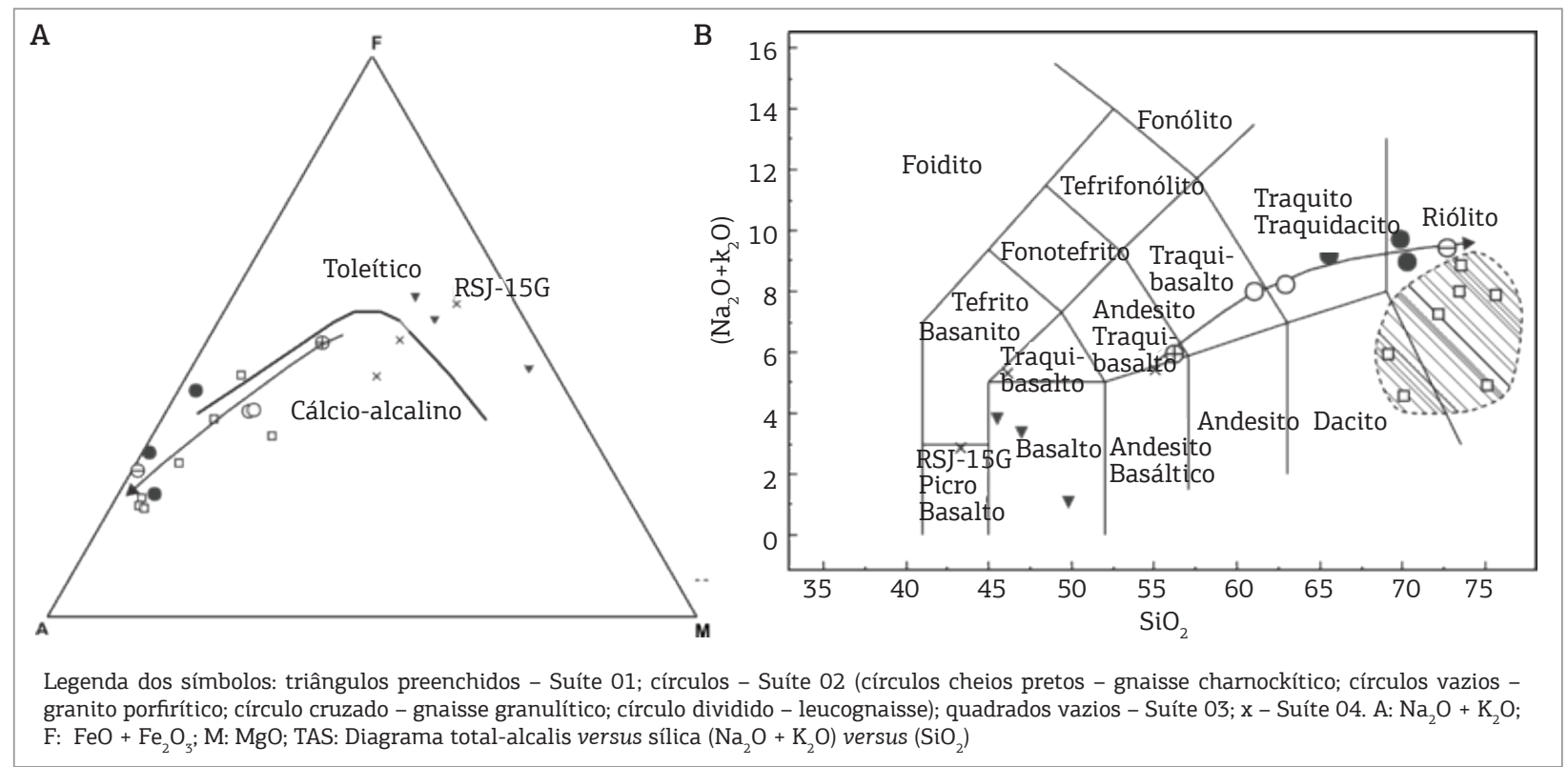

Figura 5. Diagramas de classificação geoquímica. (A) AFM (Irvine \& Baragar, 1971); (B) TAS (Le Bas et al. 1986).

químicas entre as suítes. Assim, observando-se o comportamento das Suítes 02 e 03, nota-se que a Suíte 02 apresenta ampla variação composicional em uma tendência ("trend") magmática que parte do gnaisse granulítico (composição intermediária), passando para granito porfrítico, gnaisse charnockítico até leucognaisse (ácido), enquanto a Suíte 03 não apresenta "trend". Além disso, os diagramas de $\mathrm{SiO}_{2}$ versus $\mathrm{CaO}, \mathrm{MgO}, \mathrm{K}_{2} \mathrm{O}$ e $\mathrm{MnO}$ mostram que a Suíte 03 não se insere na linha de tendência da Suíte 02.

\section{Elementos menores}

Dentre os elementos menores analisados, destacam-se os comportamentos do $\mathrm{Sr}$, $\mathrm{Rb}$ e $\mathrm{Zr}$, bem como das razóes $\mathrm{Ba} / \mathrm{Sr}$ e K/Rb das Suítes 02 e 03 (Figs. 6 e 7).

A Suíte 03 apresenta valores baixos a moderados da razão $\mathrm{Ba} / \mathrm{Sr}(1,51$ - 5,65), enquanto que a Suíte 02 apresenta uma maior variação de valores $(1,6-8,75)$. Os maiores valores para a Suíte 02 são observados nos leucognaisses e gnaisses charnockíticos $(4,86-8,75)$, enquanto que, nos granitos porfiríticos, os valores variam de 2,4 a 2,72.

A razão K/Rb das Suítes 02 e 03 é moderada $(<450)$ e, no geral, é mais alta na Suíte 02 que na Suíte 03. Varia entre 102,79 e 561,98 para a Suíte 01 e menor que 280 para a Suíte 04 .

Quanto aos valores de \#mg, na Suíte 03 variam no geral entre 26,4 e 34,4 . Na Suíte 02 , os maiores valores $(33,27$ a 41,9$)$ estão nos gnaisses granulíticos e hornblenda granitos; já no leucognaisse e nos gnaisses charnockíticos, esses valores são baixos $(<12)$.

\section{Elementos terras raras}

A Fig. 8 apresenta o padráo de elementos terras raras (ETR) normalizados pelo condrito de Sun e McDonough (1989).

As amostras da Suíte 01 apresentam padrão de distribuição dos ETR sub-horizontal com sutil enriquecimento em elementos terras raras leves (ETRL) em relação aos elementos terras raras pesados (ETRP), onde a razão $(\mathrm{La} / \mathrm{Yb}) \mathrm{N}$ varia de 2,5 a 4,2 e a de Eu/Eu*, entre 1,08 e 1,10.

A Suíte 02 apresenta enriquecimento moderado em ETR, e a razão (La/Yb)N varia entre 11,3 e 16,2. Quanto ao $\mathrm{Eu}$, todas as amostras apresentam anomalias negativas, sendo que o leucognaisse (RSJ-17) apresenta o menor valor da razão $\mathrm{Eu} / \mathrm{Eu}^{*}(0,34)$, que aumenta gradativamente para o gnaisse charnockítico $(0,65$ a 0,78$)$, para o granito porfirítico $(0,89)$ e para o gnaisse granulítico $(0,86)$.

As amostras da Suíte 03 apresentam os mais pronunciados valores da razáo $(\mathrm{La} / \mathrm{Yb}) \mathrm{N}(17,7$ - 50,6), revelando forte fracionamento de ETR; a exceção é a amostra RSJ $10 \mathrm{D}$, que apresenta baixa razão $(\mathrm{La} / \mathrm{Yb}) \mathrm{N}(5,2)$, já que, nessa amostra, não há empobrecimento em ETRP. A razão $(\mathrm{La} / \mathrm{Sm}) \mathrm{N}$ é baixa a moderada e varia entre 3,19 e 5,08. No geral, as amostras desse grupo apresentam anomalias de $\mathrm{Eu}\left(\mathrm{Eu} / \mathrm{Eu}^{*}=0,42-0,99\right)$, que variam de moderada a nula, sendo a amostra RSJ-10F a exceção, apresentando incipiente anomalia positiva $\left(\mathrm{Eu} / \mathrm{Eu}^{*}=1,18\right)$.

A Suíte 04 é representada apenas pelo biotita - diopsídio anfibolito (RSJ-15). Essa amostra apresenta baixo valor de $(\mathrm{La} / \mathrm{Yb}) \mathrm{N}(4,15)$ e praticamente náo apresenta anomalia de $\mathrm{Eu}\left(\mathrm{Eu} / \mathrm{Eu}^{*}=0,97\right)$. Portanto, assim como as 

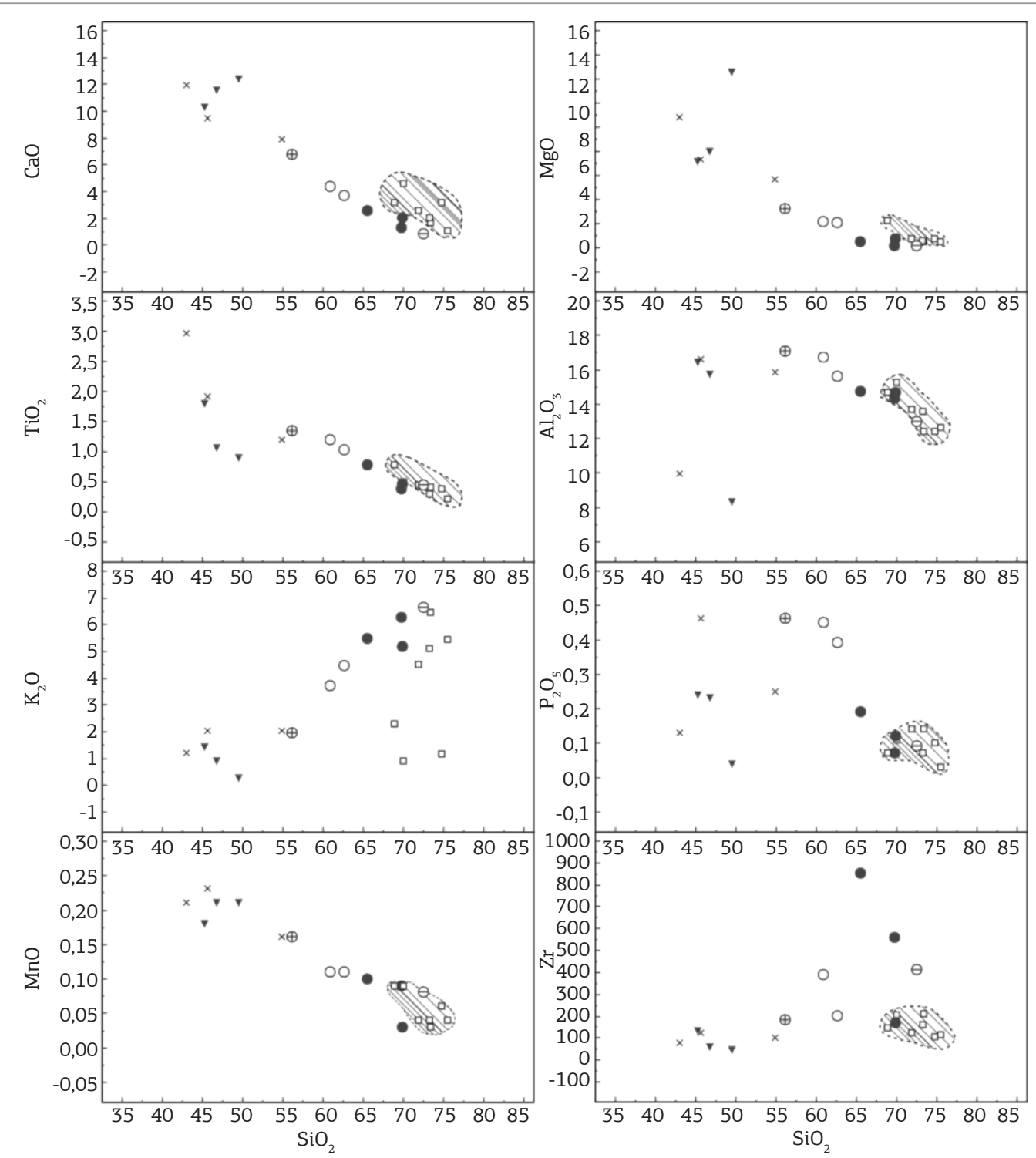

Legenda dos símbolos: triângulos preenchidos - Suíte 01; círculos - Suíte 02 (círculos cheios pretos - gnaisse charnockítico; círculos vazios granito porfirítico; círculo cruzado - gnaisse granulítico; círculo dividido - leucognaisse); quadrados vazios - Suíte $03 ; \mathrm{x}-\mathrm{Su}$ íte 04 . $\mathrm{A}_{\mathrm{N}} \mathrm{Na}_{2} \mathrm{O}+\mathrm{K}_{2} \mathrm{O}$; $\mathrm{F}: \mathrm{FeO}+\mathrm{Fe}_{2} \mathrm{O}_{3}$; M: MgO; TAS: Diagrama total-alcalis versus sílica $\left(\mathrm{Na}_{2} \mathrm{O}+\mathrm{K}_{2} \mathrm{O}\right)$ versus $\left(\mathrm{SiO}_{2}\right)$

\section{Figura 6. Diagramas binários (Harker) de elementos maiores e Zr.}

amostras da Suíte 01, apresenta padrão de distribuição dos ETR aproximadamente horizontal.

\section{Discussão dos dados geoquímicos}

\section{Migmatitos (Suíte 01 e Suíte 03)}

Comparando-se a razão $\mathrm{Ba} / \mathrm{Sr}$ e os valores de $\mathrm{Rb}$, Ba e outros elementos incompatíveis entre Suíte 03 (neossomas leucocráticos de composição granítica) e a Suíte 01 (paleossomas ortogranulíticos básicos), nota-se que o grau de enriquecimento em alguns elementos incompatíveis durante a fusão parcial, a partir dos ortogranulitos básicos, foi elevado (Fig. 8). Esse enriquecimento pode chegar a dez vezes a concentração encontrada nas amostras da Suíte 01 para alguns elementos, o que sugere baixa taxa de fusão para a formação de neossomas graníticos (Suíte 03) a partir de rochas básicas.

É comum baixa razão $\mathrm{Ba} / \mathrm{Sr}$ em rocha básica, visto que o $D_{(\mathrm{Ba})}$ em magma básico é menor que em magma ácido, com mais feldspato rico em K. Destaca-se que os valores de Ba e Sr para a Suíte 01 são próximos aos valores de basaltos toleíticos de arco de ilha de Sun (1980), bem como as razóes $\mathrm{Ba} / \mathrm{Sr}$.

Dados de temperatura de saturação de zircão, apresentados por Janasi (1997), de granitos do tipo Pinhal sugerem temperaturas entre 820 e $870^{\circ} \mathrm{C}$; comparando-se os valores de $\mathrm{Zr}$ de Janasi (1997) com os valores obtidos nas análises das amostras da Suíte 03, observa-se que os deste último são mais baixos (106 - 209 ppm). 

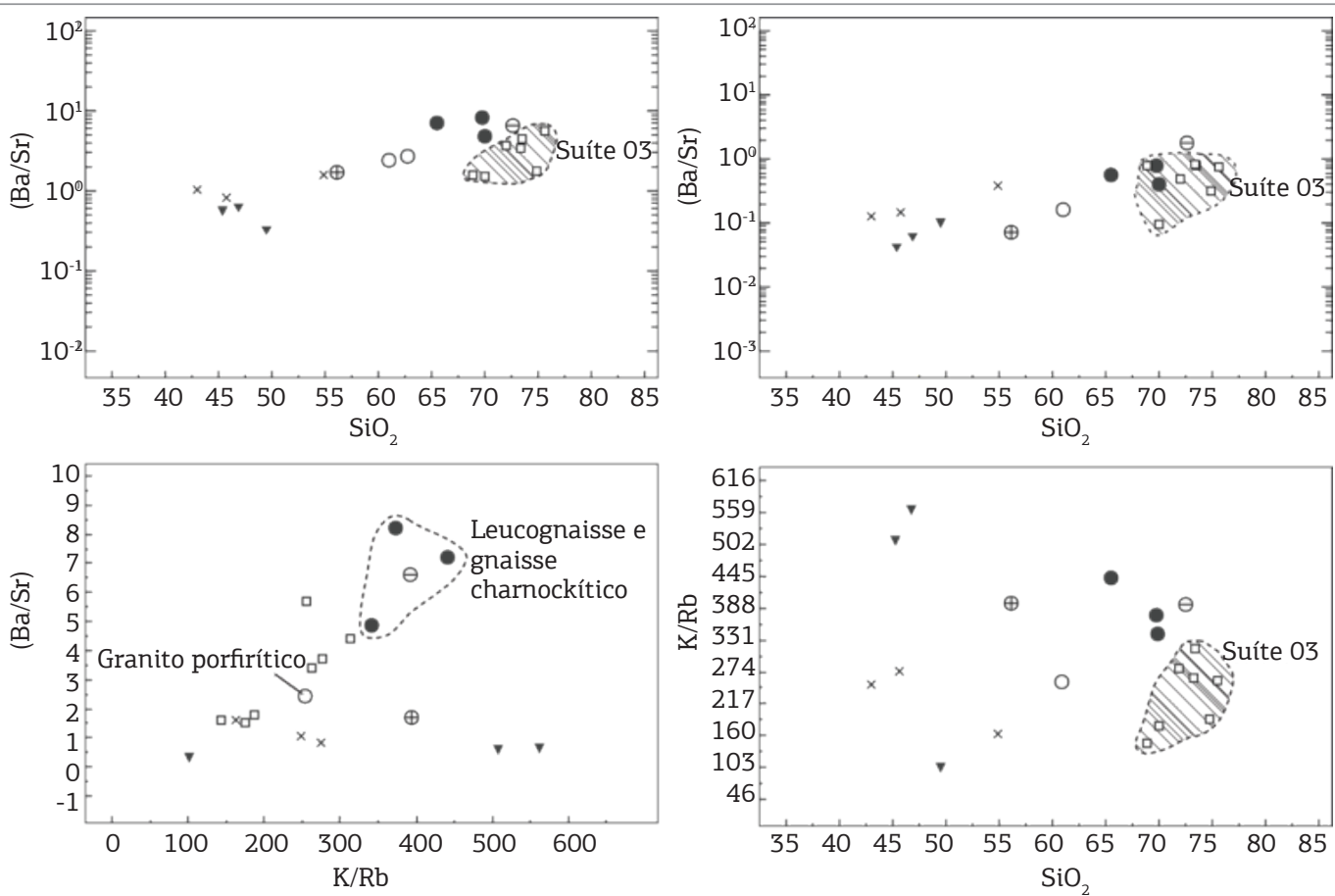

Legenda dos símbolos: triângulos preenchidos - Suíte 01; círculos - Suíte 02 (círculos cheios pretos - gnaisse charnockítico; círculos vazios granito porfirítico; círculo cruzado - gnaisse granulítico; círculo dividido - leucognaisse); quadrados vazios - Suíte 03; $\mathrm{x}-\mathrm{Suíte} 04$. A: $\mathrm{Na}_{2} \mathrm{O}+\mathrm{K}_{2} \mathrm{O}$; $\mathrm{F}: \mathrm{FeO}+\mathrm{Fe}_{2} \mathrm{O}_{3} ; \mathrm{M}: \mathrm{MgO}$; TAS: Diagrama total-alcalis versus sílica $\left(\mathrm{Na}_{2} \mathrm{O}+\mathrm{K}_{2} \mathrm{O}\right)$ versus $\left(\mathrm{SiO}_{2}\right)$

Figura 7. Diagramas binários de $\mathrm{SiO}_{2}$ versus as razões $\mathrm{K} / \mathrm{Rb}, \mathrm{Ba} / \mathrm{Sr}$ e $\mathrm{Rb} / \mathrm{Sr}$ e $\mathrm{Ba} / \mathrm{Sr}$ versus $\mathrm{K} / \mathrm{Rb}$.

Melo (2009) apresenta valores de cálculos geotermobarométricos onde o pico metamórfico da região foi calculado em $820^{\circ} \mathrm{C}$ de temperatura e 11,5 Kbar de pressão, considerando a fase fluida $a \mathrm{H}_{2} \mathrm{O}=0,1$.

Segundo Patiño Douce e Beard (1995), a fusão parcial de quartzo-anfibolito (composição basáltica) com mais de $50 \%$ de hornblenda pode gerar um fundido fortemente granodiorítico $\left(\mathrm{SiO}_{2}>70 \%\right)$ coexistente com clinopiroxênio, ortopiroxênio, plagioclásio e quartzo em pressóes acima de 10 Kbar. Segundo Rapp e Watson (1995), a fusão de hornblenda de metabasaltos geralmente forma magmas pobres em $\mathrm{K}$, exceto em graus muito baixos de anatexia. Além disso, a análise das características da Suíte 01 e da Suíte 03 mostra que a fusão parcial de rochas toleíticas básicas pode gerar neossomas cálcio-alcalinos graníticos.

As amostras da Suíte 01 apresentam valores moderados a baixos de $\mathrm{K} / \mathrm{Rb}(<561)$, com valores de $\mathrm{Rb}$ entre 13 e 23 ppm. Quando comparadas com valores de basaltos de arcos vulcânicos e arcos de ilhas ativos, verifica-se que essas razôes de $\mathrm{K} / \mathrm{Rb}$ são mais compatíveis com basaltos de alto $\mathrm{K}$ de arcos de ilha. Da mesma forma, as razóes moderadas a baixas de K/Rb observadas na Suíte 03 são assim coerentes, considerando-se que a fonte tem taxas de $\mathrm{Rb}$ altas.

No geral, as amostras da Suíte 03 apresentam fracionamento de ETR mais expressivo, com valores da razão $(\mathrm{La} / \mathrm{Yb}) \mathrm{N}$ que chegam a 50,5, marcado pelo empobrecimento em ETRP. Segundo Rollinson (1993), o fracionamento de ETRL em relação aos ETRP pode ser causado pela presença de ortopiroxênio e clinopiroxênio na fonte, devido ao aumento do coeficiente de partição do La ao Lu em líquidos félsicos. Isso pode explicar as altas razóes de $(\mathrm{La} / \mathrm{Lu}) \mathrm{N}$ encontradas nesse grupo, visto que as rochas, no geral, são migmatitos formados pela fusão parcial de granulitos com ortopiroxênio e diopsídio.

As anomalias negativas de Eu geralmente são controladas pelos feldspatos, sendo que a retirada de feldspato pela cristalização fracionada pode causar empobrecimentos em Eu. No entanto, no caso das amostras da Suíte 03 (neossomas leucocráticos que formaram pequenos volumes de magmas exposto em bandas), a anomalia negativa de Eu deve estar mais associada à retenção de feldspato na fonte durante a fusão parcial. Esse grau de retenção deve variar conforme o grau de fusão ocorrido, o que poderia explicar as variaçóes de valores de moderadamente negativos (RSJ - 03A) a fracamente positivos (RSJ-10F).

Segundo Humphris (1984), geralmente os ETR sofrem pouca ou nenhuma remobilização durante o metamorfismo. Levando-se em conta que as rochas da Suíte 01 são paleossomas ortodevidados, com composição basáltica toleítica (Fig. 5) e, assim, sofreram pouca ou nenhuma 


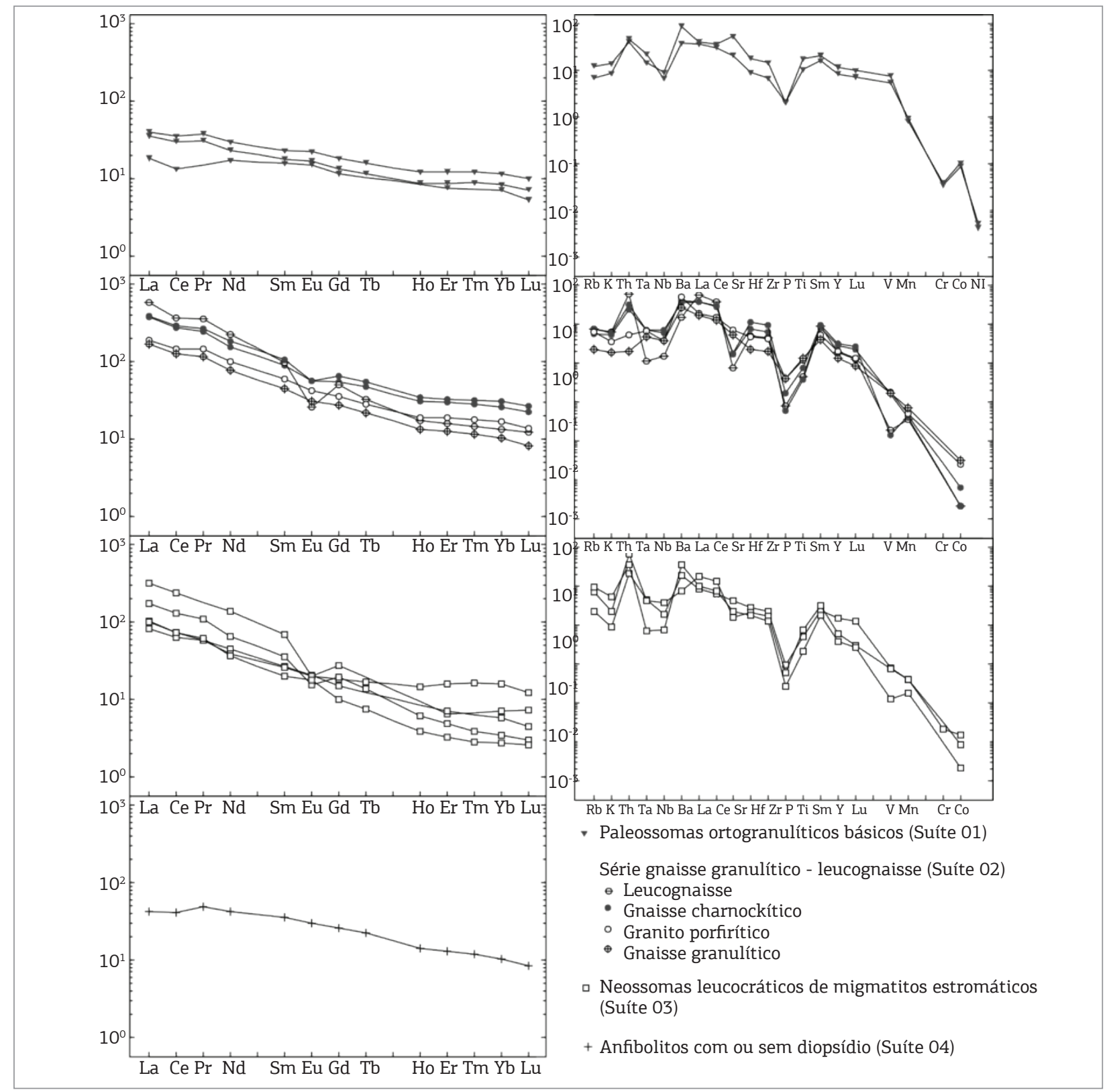

Figura 8. Padrões de distribuição de elementos terras raras (à esquerda), normalizados pelo condrito de Sun e McDonough (1989), e de elementos incompatíveis (à direita), normalizados pelo condrito de Wood et al. (1979), separados por suítes geoquímicas.

modificação geoquímica durante o metamorfismo, e que foram, de certa forma, poupadas durante a anatexia, o estudo do padrão de ETR desse grupo deve refletir aproximadamente o padrão de ETR do protólito.

O baixo fracionamento de ETR caracterizado por padrão de distribuição horizontal, quando comparado com basaltos de sistemas magmáticos ativos, mostra certa semelhança com toleítos de arcos de ilha, observados em Wilson (1989). Com enriquecimento de ETR entre 8 a 30 vezes em relação ao condrito, a Suíte 01 apresenta baixo fracionamento de ETRP e leve enriquecimento em
ETRL, provavelmente devido ao baixo grau de fracionamento magmático. Isso porque os ETR em líquidos basálticos são todos incompatíveis e, assim, são fracamente fracionados.

Levando-se em conta as características acima, as amostras da Suíte 01 foram plotadas em diagramas petrogenéticos (Fig. 9), cuja finalidade é tentar identificar o ambiente tectônico de formação do protólito. As amostras foram estudadas em dois diagramas petrogenéticos para rochas basálticas, o diagrama ternário de Pearce e Cann (1973), que confronta Ti/1000, Sr/2 e 


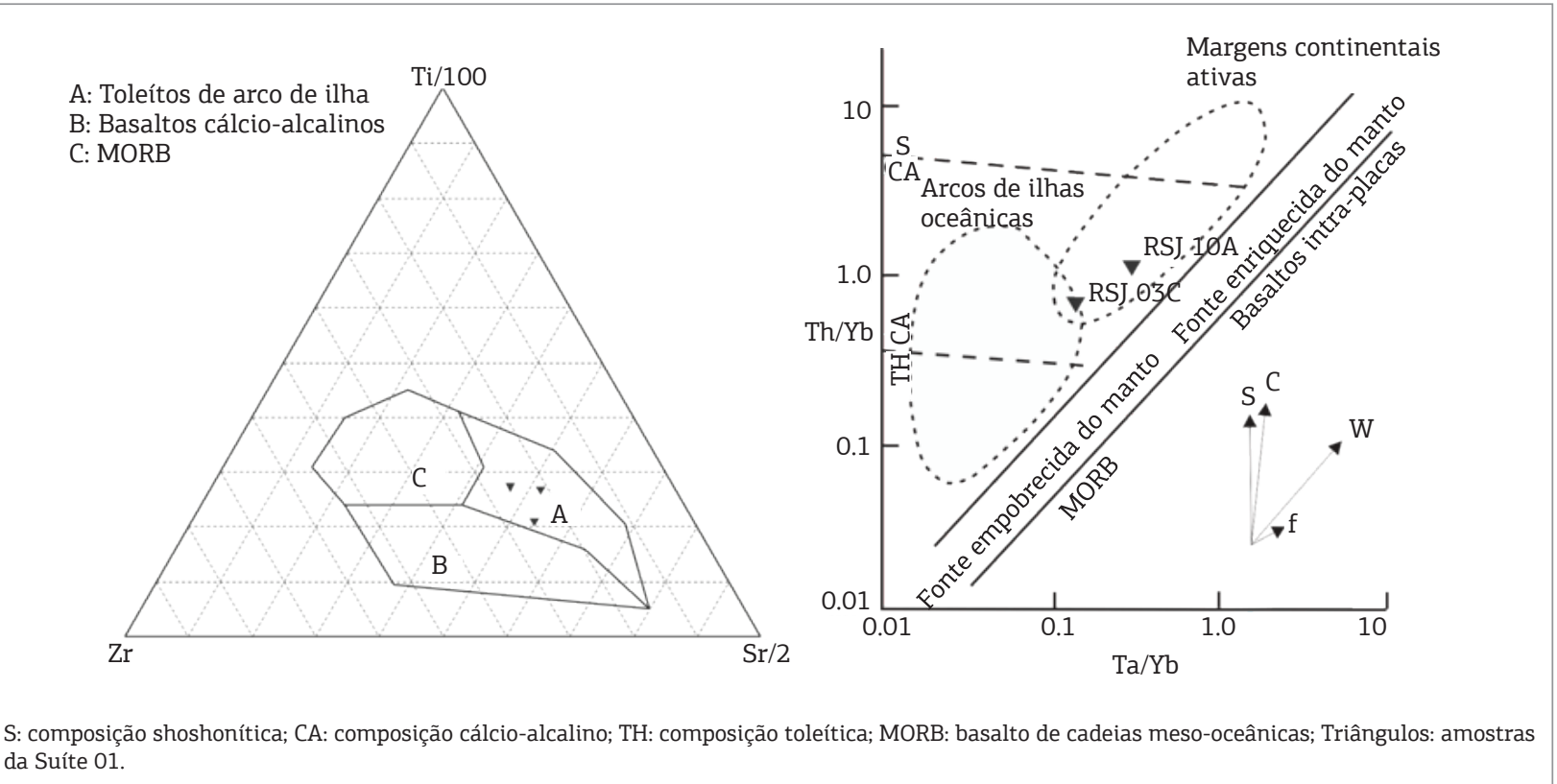

Figura 9. Diagramas binários petrogenéticos de ambiente tectônico para rochas basálticas. À esquerda, diagrama de Pearce e Cann (1973) e, à direita, diagrama de Pearce (1983).

Zr, e o diagrama binário de Pearce (1983), que confronta as razóes de $\mathrm{Th} / \mathrm{Yb}$ e $\mathrm{Ta} / \mathrm{Yb}$ (Fig. 9). Pelo diagrama de Pearce e Cann (1973), as amostras foram classificadas como basaltos toleíticos de arco de ilha, enquanto que, no diagrama de Pearce (1983), a classificação sugere ambiente de margem continental ativa para uma das amostras e a possibilidade de margem continental ativa e arco de ilha para a outra, mas com magmatismo de característica cálcio-alcalina.

Como o padrão de elementos terras raras é semelhante ao de toleítos de arco de ilha, comparou-se o padrão de distribuição de alguns elementos incompatíveis de uma das amostras da Suíte 01 (RSJ-03C) com o padrâo de basalto toleítico de arco de ilha (Fig. 10), extraído de Sun (1980) e normalizado pelo Manto Primordial de McDonough e Sun (1995). Observa-se que a amostra RSJ-03C apresenta um padrão de distribuição muito semelhante ao dos basaltos toleíticos de Arco de Ilha, embora esteja no geral mais enriquecida em elementos incompatíveis, o que sugere a possibilidade de esses granulitos básicos serem produtos de antigos sistemas magmáticos relacionados às zonas de subducção.

\section{Granitos e charnockitos (Suíte 02)}

Janasi (2002) apresenta o estudo geoquímico de duas suítes mangeríticas do SE do Brasil, sendo que uma delasSuíte São Pedro de Caldas (SPC) - engloba as rochas da Suíte 02 da presente pesquisa. Deste modo, a denominação mangerito, proposta pelo autor, corresponde aos gnaisses charnockíticos (Gch da área), assim como o hornblenda granito corresponde ao granito porfirítico (Go e Gp da área) e o leucogranito corresponde ao leucognaisse (Lg da área).

Segundo Janasi (2002), a SPC sofreu cristalização fracionada em dois estágios. O primeiro, com a formação de cumulatos mangeríticos e hornblenda granitos, em que a taxa de $\mathrm{Ba} / \mathrm{Sr}$ permaneceu constante $(-6,5-7)$ pela extração de feldspato ternário; e o segundo, marcado pela formação de hornblenda-granitos e leucogranitos, nos quais o feldspato extraído é mais rico em $\mathrm{K}$ e, assim, os magmas diferenciados desenvolveram baixa razão $\mathrm{Ba} / \mathrm{Sr}$.

$\mathrm{Ba}$, $\mathrm{Sr}$ e $\mathrm{Rb}$ são elementos presentes principalmente em feldspatos e micas. Os valores da razão $\mathrm{Ba} / \mathrm{Sr}$ da Suíte 02 (Tab. 1) mostram que o leucognaisse e os gnaisses charnockíticos (correlacionáveis aos leucogranitos e mangeritos da SPC, respectivamente) são os litotipos que apresentam as mais altas razóes de $\mathrm{Ba} / \mathrm{Sr}$ (6,5 a 8,17 ), enquanto os granitos porfiríticos (correlacionáveis ao hornblenda granito de SPC) apresentam os menores valores (2,44 e 2,72). Assim, os valores de $\mathrm{Ba} / \mathrm{Sr}$ da Suíte 02 estão, de certo modo, no sentido inverso daqueles apresentados por Janasi (2002) para a SPC.

No entanto, os gnaisses charnockíticos e os leucognaisses apresentam as maiores taxas de $\mathrm{K} / \mathrm{Rb}$, compatíveis com os valores apresentados por Janasi (2002) para os mangeritos e leucogranitos da Suíte Sáo Pedro de Caldas, que, segundo o autor, refletem uma fonte 
menos empobrecida em Rb do que aquelas que formaram os mangeritos da Suíte Divinolândia (suíte mangerítica que ocorre a norte da área de estudo), conforme abordado em Janasi (2002).

Nos diagramas de variação binária, o leucognaisse e o gnaisse charnockítico aparecem sempre no final das linhas de tendência e sempre com composição mais ácida. Os baixos valores de Ca e Sr (Tab. 1) para os leucognaisses sugerem fracionamento de plagioclásio. Observação semelhante pode ser feita com relação ao gnaisse charnockítico, no qual o feldspato é predominantemente mesopertítico e, portanto, de composição mangerítica. Ao mesmo tempo, as taxas de $\mathrm{Rb} / \mathrm{Sr}$ (Fig. 7) são mais elevadas nos gnaisses charnockíticos e leucognaisses, enquanto que, nos granitos porfiríticos, essa razão é mais baixa. Dessa forma, os dados sugerem que a evolução magmática da Suíte 02 é marcada por diferenciação magmática, na qual o leucognaisse está no final da linha de evoluçáo, como produto do fracionamento magmático, sendo, no entanto, o granito porfirítico o termo menos fracionado da série.

Observa-se que valores de $\mathrm{Zr}$ de leucognaisses, gnaisses charnockíticos e granitos porfiríticos da Suíte 02 são semelhantes aos de algumas amostras de Janasi (2002) respectivamente para mangeritos, hornblenda granitos e leucogranitos, sendo que os mangeritos apresentam os maiores valores. Segundo Janasi (2002), os magmas da SPC foram saturados em zircáo e registram temperatura de saturação em torno de 965 a $980^{\circ} \mathrm{C}$

Com valores moderados de $(\mathrm{La} / \mathrm{Lu}) \mathrm{N}$, o fracionamento de ETR na Suíte 02, no geral, não é tão expressivo quanto o que ocorre na Suíte 03.

Segundo Janasi (2002), os ETRL da Suíte São Pedro de Caldas são fortemente incompatíveis, enquanto que os ETRP estão fracionados pela extração de zircão e apatita.

Para as amostras da Suíte 02, observa-se que a amostra de leucognaisse (RSJ-17) é a que apresenta o maior valor de fracionamento de ETR e forte anomalia negativa de Eu. O alto valor de $(\mathrm{La} / \mathrm{Yb}) \mathrm{N}$ deve estar relacionado com o fracionamento de allanita e outros minerais acessórios. Já a anomalia negativa de Eu, observada tanto na amostra de leucognaisse como nas amostras de gnaisse charnockítico, possivelmente está relacionada à extração de plagioclásio por fracionamento magmático; porém, no caso dos ETRL, o forte enriquecimento deve estar relacionado com o feldspato potássico, já que, segundo Bea (1996), normalmente nessas rochas o conteúdo desses elementos é relativamente alto.

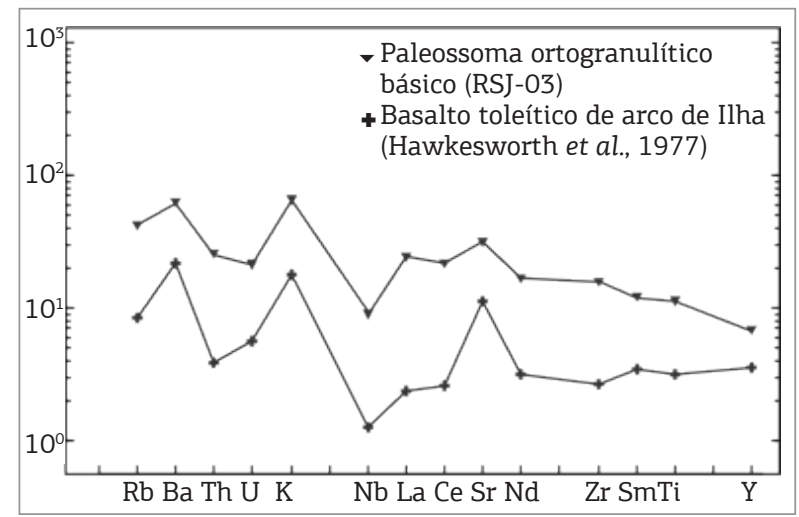

Figura 10. Comparativo entre o padrão de distribuição de elementos incompatíveis da amostra RSJ-03C (paleossoma ortogranulítico básico) e o padrão de basalto de Arco de Ilha de Sun (1980), ambos normalizados pelo manto primordial de McDonough e Sun (1995).

Quanto à fonte, segundo Janasi (2002), muitos autores têm sugerido que a geração das rochas mangeríticas está associada à fusão de crosta granulítica sem a adição de material máfico de magmas derivados do manto, sendo, no entanto, desconhecidas rochas máficas diretamente associadas com mangeritos da Suíte São Pedro de Caldas, e a composição média do magma fundido é mais máfico. Além disso, a característica anidra dos mangeritos indicaria que, se são produtos de anatexia crustal, suas fontes eram nulas em biotita e hornblenda, já que a fusão crustal com baixa $a \mathrm{H}_{2} \mathrm{O}$ $(0,1)$ requer altas temperaturas $\left(-950^{\circ} \mathrm{C}\right)$ e pressão em torno de $10 \mathrm{Kbar}$, temperaturas estas que não são usualmente alcançadas na crosta, exceto quando um substancial volume de magma básico está presente. Por fim, a fusão de rochas cálcio-alcalinas, mesmo a altas temperaturas, resultaria em magmas félsicos; tais fontes são muito oxidadas para gerar baixos valores de \#mg.

O fato é que ortogranulitos básicos toleíticos (Suíte 01) ocorrem logo a sul da intrusão granito charnockítica (Suíte 02) e possuem conteúdo moderado de minerais hidratados (anfibólio e biotita). Além do mais, como citado anteriormente, dados geotermobarométricos da área apresentam temperatura de $820^{\circ} \mathrm{C}$ e pressão de 11,5 Kbar para o pico metamórfico, valores estes suficientes para causar a fusão parcial de crosta granulítica de composição basáltica.

Os valores de \#mg das rochas menos diferenciadas da Suíte 02 (granito porfirítico) são compatíveis com os valores apresentados para a Suíte 03 , enquanto que as rochas mais diferenciadas (ganisse charnockíticos e leucognaisse) apresentam valores bem menores, sugerindo 
que os valores mais baixos poderiam ser decorrentes do fracionamento magmático (Fig. 7).

Os teores de K para as amostras da Suíte 02 apresentam ampla variaçáo, táo ampla quanto o observado para as amostras da Suíte 03, e as taxas de K/Rb da Suíte 02 sáo compatíveis com fontes com altos valores de $\mathrm{Rb}$, como observado na Suíte 01.

Entretanto, o estudo dos diagramas de variação binária de $\mathrm{SiO}_{2}$ versus outros óxidos mostram que a composição química da Suíte 03 , no geral, não cai dentro da linha de tendência evolutiva observada na Suíte 02 . Além disso, o dado mais marcante é que a Suíte 02 geralmente é mais enriquecida em ETR (tanto ETRL como ETRP) do que a Suíte 03, o que sugere uma fonte previamente mais enriquecida do que aquela que gerou os neossomas dos migmatitos.

O gnaisse granulítico bandado que ocorre logo a norte da intrusấo granito-charnockitica é, na verdade, um ortogranulito de composiçáo diorítica composto por oligoclásio/andesina, ortopiroxênio, diopsídio, hornblenda quartzo e biotita. Ocorre intercalado com bandas leucocráticas de composiçáo tonalítica a granodiorítica, e suas características geoquímicas o colocam dentro da linha de evoluçấo desses mangeritos. Assim, por suas características geoquímicas, bem como por seu contexto geológico, sugere-se que essas rochas representem o protólito dessas intrusóes granito-charnockíticas ou, pelo menos, o mais próximo disso, já que são as rochas menos evoluídas da Suíte 02 .

\section{OBSERVAÇÕES FINAIS}

A exumação do Complexo Guaxupé foi acompanhada de extensiva anatexia, que gerou os migmatitos presentes principalmente na porçâo sul dessa unidade. Observaçôes de campo acerca dos migmatitos apontam para duas fases de migmatização, sendo a primeira fase caracterizada pela presença de neossomas de composição ácida, com bandas leucocráticas de cor cinza de pequena espessura, e a segunda, marcada por leucossomas/neossomas de cor rósea e composição granítica. O bandamento composicional, assinalado pela intercalação de leucossoma, melanossoma e mesossoma, é paralelo à foliação principal da área, com direção WNW e mergulho para SW.

Os ortogranulitos encontrados em paleossomas de migmatitos da porção sul e central são rochas básicas, toleíticas e apresentam fortes semelhanças geoquímicas com basaltos toleíticos formados em arcos de ilhas vulcânicas. A fusão parcial desses ortogranulitos básicos gerou neossomas de composição granítica, cálcio-alcalina, com valores moderados de \#mg e altos teores de $\mathrm{Rb}$. A assinatura de ETR é marcada pelo forte fracionamento em ETRL em relação ao ETRP, sugerindo que a fusão parcial ocorreu na presença de ortopiroxênio e clinopiroxênio. As anomalias negativas a fracamente positivas de Eu sugerem retençáo de feldspato na fonte durante a fusão parcial devido ao baixo grau de fusão dessas rochas. No entanto, o grau de fusão deve ter sido variável na área, justificando, assim, a variação da razão $\mathrm{Eu} / \mathrm{Eu}^{*}$, o que se coaduna com a diversidade de tipos de estruturas de migmatitos encontrados, estromático e dobrado até migmatitos nebulíticos.

A presença, náo rara, de paragnaisses de composição metapelítica (alto $\mathrm{Al}$ ) e cálcio-silicática demonstra que, durante a evolução do Complexo Guaxupé, metassedimentos estiveram presentes e foram metamorfisados em grandes profundidades na crosta. Sedimentos siliciclásticos deram origem a paragnaisses de alto grau metamórfico, com granada silimanita e cordierita denominados gnaisses kinzigíticos, que são normalmente encontrados como paleossomas de migmatitos na porção sul da área de estudo.

Durante a evolução do Complexo Guaxupé, ocorreu expressivo magmatismo cálcio-alcalino charnockítico, que gerou uma série magmática formada por granitos com textura porfirítica, bem como charnockitos mageríticos e leucogranitos, que posteriormente foram gnaissificados como efeito da deformação durante a própria evolução da unidade. Esse magmatismo é facilmente identificado no mapa geológico devido a sua expressão e ocorrência geográfica restrita à porção $\mathrm{NE}$ da área de pesquisa. Essas rochas apresentam tendência evolutiva caracterizada por diferenciação magmática em que o leucogranito é o produto final da diferenciação, dada pelo fracionamento de minerais acessórios, como allanita e zircão, bem como plagioclásio.

As diferenças químicas entre o magmatismo charnockítico da região nordeste da área e os neossomas produzidos pela fusão parcial de ortogranulitos básicos deixam dúvidas sobre a possibilidade de serem produtos de uma mesma fonte, formados em um mesmo evento. Apesar de ter valores de \#mg compatíveis com fontes básicas, o padrão geoquímico de alguns elementos maiores e a assinatura geoquímica de ETR da rochas charnockíticas sugerem fonte diferente daquela dos neossomas. Por outro lado, o padrấo geoquímico de gnaisses granulíticos bandados de composição diorítica, que ocorrem a NE da intrusão charnockítica, sugere que a geração desses corpos 
granito charnockíticos poderiam ter se formado pela fusão parcial desses ortogranulitos durante o pico metamórfico da área.

A exumação final do Complexo Guaxupé se deu em ambiente dúctil-rúptil, no qual uma fase tardia de fusão parcial é marcada pela presença de pequenos corpos magmáticos (pegmatitos, aplitos e granitos) discordantes.

\section{AGRADECIMENTOS}

Os autores agradecem aos revisores anônimos do trabalho, pelas observaçóes e sugestôes oferecidas, bem como à Fundação de Amparo à Pesquisa do Estado de São Paulo (FAPESP), pelo auxílio financeiro para execução desta pesquisa (Processo 06/58128-9).

\section{REFERÊNCIAS}

Bea F. 1996. Residence of REE, Y, Th and U in granites and crustal protoliths, implications for the chemistry of crustal melts. Journal of Petrology, 37(3):521-552

Campos Neto M.C. \& Caby R. 2000. Terrane accretion and upward extrusion of high-pressure granulites in the Neoproterozoic nappes of Southeast Brazil: petrological and structural constraints. Tectonics, 19:669-687.

Campos Neto M.C., Basei M.A.S., Alves F.R., Vasconcelos A.C.B.A. 1984. Nappe de Cavalgamento Socorro (SP-MG). In: SBG, XXXIII Congresso Brasileiro de Geologia, 1984. Rio de Janeiro. Anais... p. 1809-1822.

Campos Neto M.C., Figueiredo M.C.H., Janasi V.A., Basei M.A.S., Freyer B.J. 1988. The São José do Rio Pardo mangeritic-granitic suite, southeastern Brazil. Geochimica Brasiliensis, 2:185-200.

Campos Neto M.C. 2000. Orogenic system from southwestern Gondwana, an aproach to Brasiliano-Pan-African cycle and orogenic collage in southeastern Brazil. In: U. G. Cordani et al. (eds.) Tectonic evolution of South America. Rio de Janeiro, Geological Society, p. 335-365.

Del Lama E.A., Zanardo A., Oliveira M.A.F. 2000. Exhumation of High-Pressure Granulites of the Guaxupé Complex, Southeastern Brazil. Geological Journal, 35:231-249.

Fonseca M.J.G., Silva Z.C.G., Campos D.A., Pierluigi T. 1979. Carta Geológica do Brasil ao Milionésimo: Folhas Rio de Janeiro (SF.23), Vitória (SF.24) e Iguape (SG.23). Brasília, DNPM (Departamento Nacional de Produção Mineral), 240 p.

Frost B.R. \& Frost C.D. 2008. On charnockites. Gondwana Research, 13(1):30-44

Godoy A.M., Morales N., Zanardo A., Oliva A. 1999. Geologia e geoquímica das rochas graníticas da Zona de Sutura Alterosa, região de São Pedro da União - MG. Geociências, 18(2):417-437.

Hawkesworth C.J., O'Nions R.K., Pankhurst R.J., Hamilton P.J. \& Evensen N.M. 1977. A geochemical study of island-arc and back-arc tholeites from the Scotia Sea. Earth and Planetary Science Letters 36:253-262

Humphris S.E. 1984. The mobility of rare earths in the crust. In P. Henderson (ed.) Rare earth element geochemistry. Amsterdam, Elsevier, p. 317-342.

Irvine T.N. \& Baragar W.R.A. 1971. A guide to chemical classification of the common volcanic rocks. Canadian Journal of Earth Science, 8:523-548

Janasi V.A. 1997. Crustal anatexis and granite genesis in the SocorroGuaxupé Thrust Nappe, southeastern Brazil: some constraints from elemental geochemistry. Revista Brasileira de Geociências, 27(1):139-150
Janasi V.A. 2002. Elemental and Sr-Nd isotope geochemistry of two Neoproterozoic mangerite suites in SE Brazil: implications for the origin of the magerite-charnockite-granite series. Precambrian Research, 119:301-327.

Kretz R. 1983. Simbols for rocks forming minerals. American Mineralogist, 68:277-279.

Le Bas M.J., Le Maitre R.W., Streckeisen A., Zanettin B. 1986. A chemical classification of volcanic rocks based on the total alkalisilica diagram. Journal of Petrology, 27:745-750.

McDonough W.F. \& Sun S.S. 1995. The composition of the Earth Chemical Geology, 120:223-254

Mehnert K.R. 1968. Migmatites and the origin of Granitic Rocks. Amsterdam, Elsevier, 363 p

Melo R.P. 2009. Evolução Metamórfica (P-T-t) de Granulitos e Migmatitos do Complexo Guaxupé na Região de São João da Boa Vista, SP. Dissertação de Mestrado, Instituto de Geociências e Ciências Exatas, Universidade Estadual Paulista "Júlio de Mesquita Filho", $162 \mathrm{p}$

Morales N. 1988. Evolução Lito-Estrutural das Rochas Pré-Cambrianas da Região de São João da Boa Vista. Dissertação de Mestrado, Instituto de Geociências, Universidade de São Paulo, 157 p.

Morales N. \& Hasui Y. 1990. Tectônica do Complexo Varginha na Região de São João da Boa Vista (SP). Geociências, 9:35-54.

Moreno M.M.T., Malagutti M.I.A., Nardy A.J.R. 1997. Determinação de Elementos Traços em Rochas Silicáticas por Espectrometria de Emissão Atômica em Plasma de Argônio Indutivamente Acoplado (ICP-AES) utilizando nebulizador ultrassônico. In: SBGeoq, VI Congresso Brasileiro de Geoquímica, Anais, v. 3, p. 361-364.

Oliveira M.A.F., Morales N., Fúlfaro V.J. 1984. Projeto Boa Vista. Rio Claro, Pro-Minério, Relatório Final 1, 85 p.

Patiño Douce A.E. \& Beard J.S. 1995. Dehydration-melting of biotite gneiss and quartz amphibolite from 3 to 15 kbar. Journal of Petrology, 36(3):707-738

Pearce J.A. \& Cann J.R. 1973. Tectonic setting of basic volcanic rocks determined using trace element analyses. Earth and Planetary Science Letters, 19:290-300

Pearce J.A. 1983. The role of sub-continental lithosphere in magma genesis at destructive plate margins. In: C. J. Hawkesworth \& M. J. Norry (eds.) Continental basalts and mantle xenoliths. Nantwich Shiva, p. 230-49.

Rapp R.P. \& Watson E.B. 1995. Dehydration melting of metabasalt at 8-32 kbar: implications for continental growth and crust-mantle recycling. Journal of Petrology, 36(4):891-931. 
Rollinson H. 1993. Using Geochemical Data: Evaluation, Presentation, Interpretation. London, Longman, $352 \mathrm{p}$.

Sun S.S. 1980. Lead isotopic study of young from mid-ocean ridges, ocean island and island arcs. Philosophical Transactions of the Royal Society of London, A297:409-445.

Sun S.S. \& Mcdonough W.F. 1989. Chemical and isotopic systematics of oceanic basalts: implications for mantle composition and processes. In: A. D. Sanders \& M. J. Norry (eds.) Magmatism in ocean basins. London, Geological London Society Special Publication, v. 42, p. 315-345.

Wilson M. 1989. Igneous petrogenesis. A global tectonic aproach. London, Unwin Hyman, 466 p.

Wimmenauer W. \& Brihni I. 2007. 6. Migmatites and related rocks. Disponível em: www.bgs.ac.uk/SCMR/docs/papers/paper\%5F6.pdf. Acessado em 11/05/2013.

Wood D.A., Joron J.L., Treuil M. 1979. A re-appraisal of the use of trace elements to study classify and discriminate between magma series erupted in different tectonic settings. Earth and Planetary. Science Letters, 45:326-336.

Zanardo A. 2003. Pesquisa Geológica e de Matérias-Primas Cerâmicas do centro Nordeste do estado de São Paulo: Sistematização Crítica da Produção Técnico-Científica. Livre-docência, Instituto de Geociências e Ciências Exatas, Universidade Estadual Paulista "Júlio de Mesquita Filho", $283 \mathrm{p}$

Zanardo A., Del Lama E.A., Morales N., Oliveira M.A.F. 1996. Geologia da Porção Limítrofe entre os Blocos São Paulo e Brasília. Geociências, 15:143-168.

Zanardo A., Morales N., Farias de Oliveira M.A., Del Lama E.A. 2006. Tectono-Lithologic associations of the Alterosa Paleo Suture Zone - Southeastern Brazil. Revista UnG - Geociências, 5(1):103-117.

Arquivo digital disponível on-line no site www.sbgeo.org.br 